\title{
Bounce Rock-A shergottite-like basalt encountered at Meridiani Planum, Mars
}

Jutta ZIPFEL ${ }^{1 *}$, Christian SCHRÖDER ${ }^{2 \dagger}$, Bradley L. JOLLIFF ${ }^{3}$, Ralf GELLERT ${ }^{4}$, Kenneth E. HERKENHOFF ${ }^{5}$, Rudolf RIEDER ${ }^{6}$, Robert ANDERSON ${ }^{7}$, James F. BELL III $^{8}$, Johannes BRÜCKNER ${ }^{6}$, Joy A. CRISP ${ }^{7}$, Philip R. CHRISTENSEN ${ }^{9}$, Benton C. CLARK ${ }^{10}$, Paulo A. DE SOUZA JR. ${ }^{11}$, Gerlind DREIBUS ${ }^{6}$, Claude D'USTON ${ }^{12}$, Thanasis ECONOMOU ${ }^{13}$, Steven P. GOREVAN ${ }^{14}$, Brian C. HAHN ${ }^{15}$, Göstar KLINGELHÖFER ${ }^{2}$, Timothy J. MCCOY ${ }^{16}$, Harry Y. MCSWEEN JR. ${ }^{17}$, Douglas W. MING ${ }^{18}$, Richard V. MORRIS ${ }^{18}$, Daniel S. RODIONOV ${ }^{2}$, Steven W. SQUYRES ${ }^{8}$, Heinrich WÄNKE ${ }^{6}$, Shawn P. WRIGHT ${ }^{19}$, Michael B. WYATT ${ }^{20}$, and Albert S. YEN ${ }^{7}$

${ }^{1}$ Sektion Meteoritenforschung, Senckenberg Forschungsinstitut und Naturmuseum Frankfurt, Senckenberganlage 25, 60325 Frankfurt a. M., Germany

${ }^{2}$ Institut für Anorganische Chemie und Analytische Chemie, Johannes Gutenberg-Universität Mainz, Staudinger Weg 9, 55128 Mainz, Germany

${ }^{\dagger}$ Present address: Universität Bayreuth und Eberhard Karls Universität Tübingen, Sigwartstr. 10, 72076 Tübingen, Germany

${ }^{3}$ Department of Earth and Planetary Sciences, Washington University, St. Louis, Missouri 63130, USA

${ }^{4}$ Department of Physics, University of Guelph, Guelph, Ontario, Canada N1G 2W1

${ }^{5}$ Astrogeology Science Center, U.S. Geological Survey, Flagstaff, Arizona 86001, USA

${ }^{6}$ Abteilung Geochemie, Max-Planck-Institut für Chemie, Postfach 3060, 55020 Mainz, Germany

${ }^{7}$ Jet Propulsion Laboratory, California Institute of Technology, Pasadena, California 91109, USA

${ }^{8}$ Department of Astronomy, Cornell University, Ithaca, New York 14853, USA

${ }^{9}$ School of Earth and Space Exploration, Arizona State University, Tempe, Arizona 85287-6305, USA

${ }^{10}$ Lockheed Martin Corporation, Littleton, Colorado 80127, USA

${ }^{11}$ Tasmanian ICT Centre, CSIRO, GPO Box 1538, Hobart, Tasmania 7001, Australia

${ }^{12}$ Centre d'Etude Spatiale des Rayonements, F-31028 Toulouse, France

${ }^{13}$ Laboratory for Atmospheric and Space Research, Enrico Fermi Institute, Chicago, Illinois 60637, USA

${ }^{14}$ Honeybee Robotics, New York, New York 10012, USA

${ }^{15}$ Department of Geosciences, State University of New York, Stony Brook, New York 11794, USA

${ }^{16}$ Department of Mineral Sciences, National Museum of Natural History, Smithsonian Institution, Washington, District of Columbia 20560-0119, USA

${ }^{17}$ Department of Earth and Planetary Sciences, University of Tennessee, Knoxville, Tennessee 37996, USA

${ }^{18}$ Astromaterials Research and Exploration Science, NASA Johnson Space Center, Houston, Texas 77058, USA

${ }^{19}$ Institute of Meteoritics, University of New Mexico, 1 University of New Mexico, MSC03-2050, Albuquerque, New Mexico 87131, USA

${ }^{20}$ Department of Geological Sciences, Brown University, Box 1846, Providence, Rhode Island 02912, USA *Corresponding author. E-mail: jzipfel@senckenberg.de

( Received 29 January 2010; revision accepted 09 September 2010)

Abstract-The Opportunity rover of the Mars Exploration Rover mission encountered an isolated rock fragment with textural, mineralogical, and chemical properties similar to basaltic shergottites. This finding was confirmed by all rover instruments, and a comprehensive study of these results is reported here. Spectra from the miniature thermal emission spectrometer and the Panoramic Camera reveal a pyroxene-rich mineralogy, which is also evident in Mössbauer spectra and in normative mineralogy derived from bulk chemistry measured by the alpha particle X-ray spectrometer. The correspondence of Bounce Rock's chemical composition with the composition of certain basaltic shergottites, especially Elephant Moraine (EET) 79001 lithology B and Queen Alexandra Range (QUE) 94201, is very close, with only $\mathrm{Cl}, \mathrm{Fe}$, and $\mathrm{Ti}$ exhibiting deviations. Chemical analyses further demonstrate characteristics typical of Mars such as the $\mathrm{Fe} / \mathrm{Mn}$ ratio and $\mathrm{P}$ 
concentrations. Possible shock features support the idea that Bounce Rock was ejected from an impact crater, most likely in the Meridiani Planum region. Bopolu crater, $19.3 \mathrm{~km}$ in diameter, located $75 \mathrm{~km}$ to the southwest could be the source crater. To date, no other rocks of this composition have been encountered by any of the rovers on Mars. The finding of Bounce Rock by the Opportunity rover provides further direct evidence for an origin of basaltic shergottite meteorites from Mars.

\section{INTRODUCTION}

The chemical composition and physical properties of the Martian surface studied by the Viking landers from 1976 to 1982, Mars Pathfinder in 1997, and the Mars Exploration Rovers (MER) since 2004 have had a great impact on our understanding of the evolution of Mars. These data provide ground-truth for orbital experiments and allow a certain group of meteorites found on Earth to be linked to Mars. This group of meteorites was named "SNCs" after three of its members and divided into three classes: shergottites (igneous rocks subdivided into basaltic shergottites and lherzolitic shergottites), nakhlites (clinopyroxenites), and Chassigny (a dunite). Later, the classification was expanded to include the unique orthopyroxenite, Allan Hills (ALH) 84001. Relative elemental abundances and isotopic compositions of trapped atmospheric gases extracted from shock-melt pockets, namely in the basaltic shergottite Elephant Moraine (EET) 79001, provide the only direct evidence that Martian meteorites, formerly "SNCs," originated from Mars (Bogard and Johnson 1983). Relatively young crystallization ages must be considered as indirect evidence. With the exception of ALH 84001, crystallization ages range from 1300 to 200 Myr or less (Borg et al. 1997; Nyquist et al. 2001).

Martian meteorites are important because they can be analyzed in detail and at much higher precision in terrestrial laboratories than any surface material on Mars that is studied by remotely operated instruments. Most models of the geochemical evolution of Mars' mantle and crust are based on studies of the mineralogical, geochemical, and isotopic composition of such meteorites. Isotopic analyses have been used to infer early differentiation with the formation of a crust, mantle, and small core (e.g., Lee and Halliday 1997; Lugmair and Shukolyukov 1998). In comparison to Earth, the inferred bulk composition of Mars has higher abundances of moderately volatile elements ( $\mathrm{Mn}, \mathrm{Na}$, etc.) and higher $\mathrm{FeO}$ in the source region of basalts (e.g., Dreibus and Wänke 1985).

The two MER landed in January 2004 on opposite sides of Mars, more than 10,000 km apart. Mission overviews are given by Squyres et al. (2004a, 2004b, 2006a, 2006b, 2009) and Arvidson et al. (2006, 2008).
Surface analyses have revealed primarily igneous bedrock, altered to variable degrees through weathering processes at Gusev crater, and sedimentary bedrock at Meridiani Planum (Squyres et al. 2004a, 2004b). None of these materials have compositions similar to those of Martian meteorites. At Meridiani, individual small cobbles and rock fragments can be recognized easily because the vast plains are predominantly covered with fine-grained material, i.e., Martian soil. Detailed studies of some such rocks showed them to be either locally derived fragments of bedrock, potential fragments of igneous rocks or impact-breccias, or meteorites (Jolliff et al. 2006; Schröder et al. 2008). The most prominent meteorites are iron meteorites and a potential mesosiderite (Schröder et al. 2008; Fleischer et al. 2010).

In March 2004, after leaving Eagle crater, Opportunity approached an isolated rock on the plains of Meridiani Planum. Because it was close to a bounce mark from the lander's airbag and may have been struck by an airbag during the landing, the rock was dubbed "Bounce Rock." With the exception of Bopulo crater, Gusev crater, and Meridiani Planum, all other names used in this report to identify geographic features on Mars are informal and are not approved by the International Astronomical Union. Because of its large size compared to anything else that could be seen on the plains and its unusual appearance (Fig. 1), the science team decided to study Bounce Rock between sols 63 and 70 of Opportunity's surface mission. A sol is a day on Mars, $24 \mathrm{~h}$ and 40 min long.

Bounce Rock has properties very similar to those of Martian meteorites. Data from the entire MER instrument suite demonstrate that Bounce Rock is closely related to basaltic shergottites. Initially published results from individual instruments were scattered across a collection of MER papers (Arvidson et al. 2004; Bell et al. 2004; Christensen et al. 2004; Herkenhoff et al. 2004; Klingelhöfer et al. 2004; Rieder et al. 2004; Squyres et al. 2004b). This article is exclusively devoted to Bounce Rock and integrates all findings, adding further details and discussion.

\section{METHODS}

Here, we present methods applied to study a rock on Mars and related samples in laboratories on Earth. 


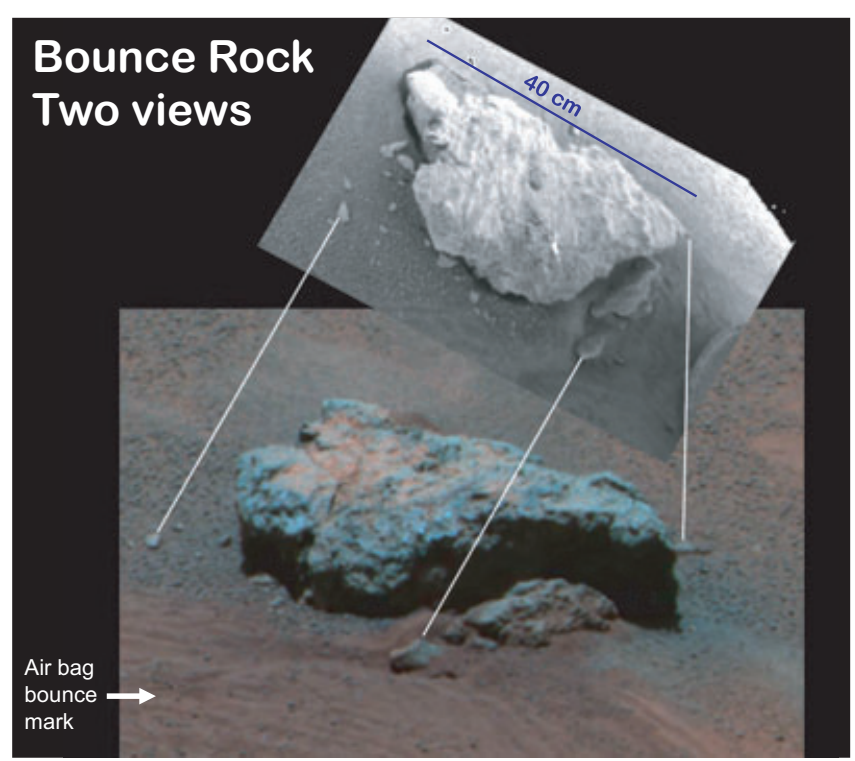

Fig. 1. "Bounce Rock predrive"-Pancam false-color image (L256) from sol 63, P2570. Effective wavelengths of the Pancam filters, L2, L5, and L6 are 753, 535, and $482 \mathrm{~nm}$, respectively. Grayscale inset is from the sol 63 Hazcam image after the approach drive. White lines connect the same features in the two views. Blue line indicates approximate scale.

For comparison to the analyses of Bounce Rock on Mars, a powdered aliquot of the Zagami meteorite was analyzed with the Alpha Particle X-ray Spectrometer (APXS) flight spare instrument, BB10, at the MaxPlanck-Institut in Mainz. An unpolished sample (butt) of EETA79001 lithology B was provided by the Meteorite Working Group and inspected in reflected light with an optical microscope. It was also analyzed with a flight spare of the Mössbauer Spectrometer (MB) at the University of Mainz. For details about the APXS and $\mathrm{MB}$ instruments, see below.

Bounce Rock was studied on Mars with instruments onboard the Opportunity rover, which is equipped with a movable instrument deployment device, a set of engineering cameras, and the Athena scientific instrument payload. The Athena payload comprises the Panoramic Camera (Pancam), the Miniature Thermal Emission Spectrometer (Mini-TES), the Rock Abrasion Tool (RAT), the Microscopic Imager (MI), the MB, and the APXS.

Pancam is a stereo camera that obtains highresolution images to assess morphology, topography, and geologic context. Thirteen narrowband filters that span a spectral range from 432 to $1009 \mathrm{~nm}$ provide information on mineralogical, photometric, and physical properties of surface materials. Details of the instrument calibration and performance are given by Bell et al. (2003, 2004, 2006).
Mini-TES is a Fourier Transform spectrometer that obtains infrared spectra from 5 to $29 \mu \mathrm{m}$ (339$1997 \mathrm{~cm}^{-1}$ ) with a spectral sampling of $10.0 \mathrm{~cm}^{-1}$. Mini-TES provides remote measurements of mineralogy and thermophysical properties of the surrounding scenery and guides the rovers to key targets for detailed in situ measurements. A detailed description of the instrument is given by Christensen et al. $(2003,2004)$.

The RAT is a brushing and grinding tool that cleans surfaces of Martian rocks of dust and debris, and exposes their fresh interior. The amount of energy needed to grind into a rock, expressed as specific grind energy (SGE), is the ratio of energy expended to the volume of material removed. The SGE is related to rock strength, primarily compressive yield strength (Gorevan et al. 2003; Arvidson et al. 2004).

The MI acquires images at a spatial resolution of $31 \mu \mathrm{m}$ per pixel over a broad, visible spectral range (400-700 nm). MI images, $3.2 \mathrm{~cm} \times 3.2 \mathrm{~cm}$ across, place other MER data in context and provide textural details to aid petrologic and geologic interpretations. Details of the instrument calibration and performance are given by Herkenhoff et al. (2003, 2004, 2008).

The MB observes a sample area approximately $1.4 \mathrm{~cm}$ in diameter in backscatter geometry. From MB spectra, one can determine Fe oxidation states, identify Fe-bearing phases, and determine relative abundances of Fe among those phases. Spectra are stored separately according to temperature. Klingelhöfer et al. (2003) and Morris et al. (2006a, 2003b) describe the instrument and data reduction procedures.

The APXS emits alpha particles and X-rays that interact with an approximately $2.5 \mathrm{~cm}$ sample area. Concentrations of major, minor and some trace elements, with $\mathrm{Z}$ ranging from $3(\mathrm{Na})$ to $35(\mathrm{Br})$, are determined from X-ray spectra. Details of the instrument calibration, and data reduction procedures are reported by Rieder et al. (2003) and Gellert et al. (2006).

In addition to the Athena payload, the rover has six engineering cameras that assist navigation and mobility. Two sets of stereo pairs of hazard avoidance cameras (Hazcam) facing front and rear are located under the rover deck. A stereo pair of navigation cameras (Navcam) is mounted on the Pancam mast. Details of these cameras are given by Maki et al. (2003).

\section{RESULTS}

\section{Textures and Physical Properties}

Bounce Rock is an isolated rock, approximately $40 \mathrm{~cm} \times 20 \mathrm{~cm}$ across, sitting on the plains of Meridiani Planum. Pancam images show that its surface is covered 

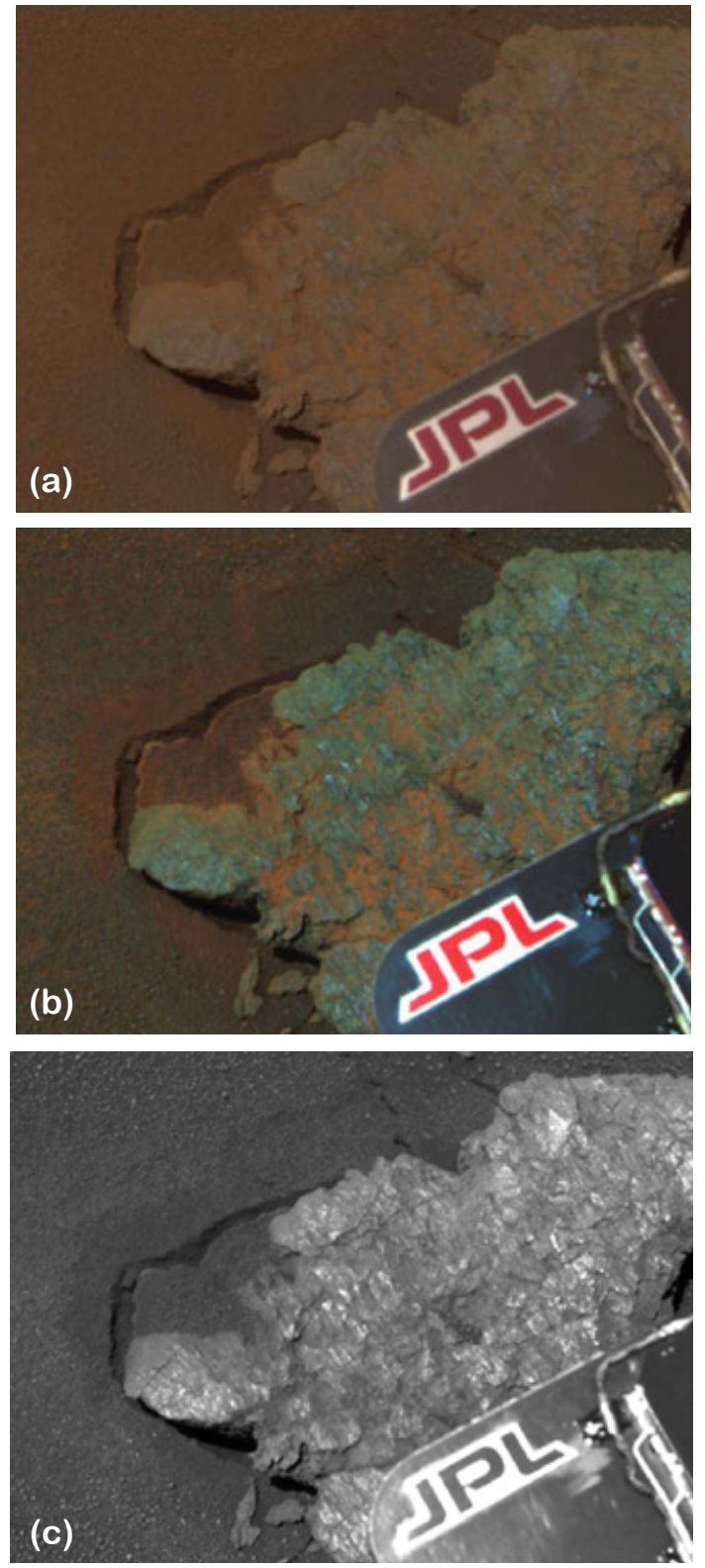

Fig. 2. Bounce Rock Pancam image from sol 65, P2574. a) Approximate true color (Savransky and Bell 2004; Bell et al. 2006). b) L257 false color. c) L7 filter, contrast stretched to enhance reflections from rock surface. Parts (b) and (c), with glinting, emphasize the striations that are reminiscent of shatter-cone textures. Image source for (a) is http:// marswatch.astro.cornell.edu/pancam_instrument/images/True/ Sol065B_P2574_1_True_RAD.jpg.

with dust and soil. Images also show that the surface displays lustrous, subparallel striations (Figs. 1-3) (Bell et al. 2004). These striations are also apparent in individual MI images and a mosaic composed of MI images of surface target "Case" (before RAT grinding; Fig. 3) (Herkenhoff et al. 2004). Nine positions on the
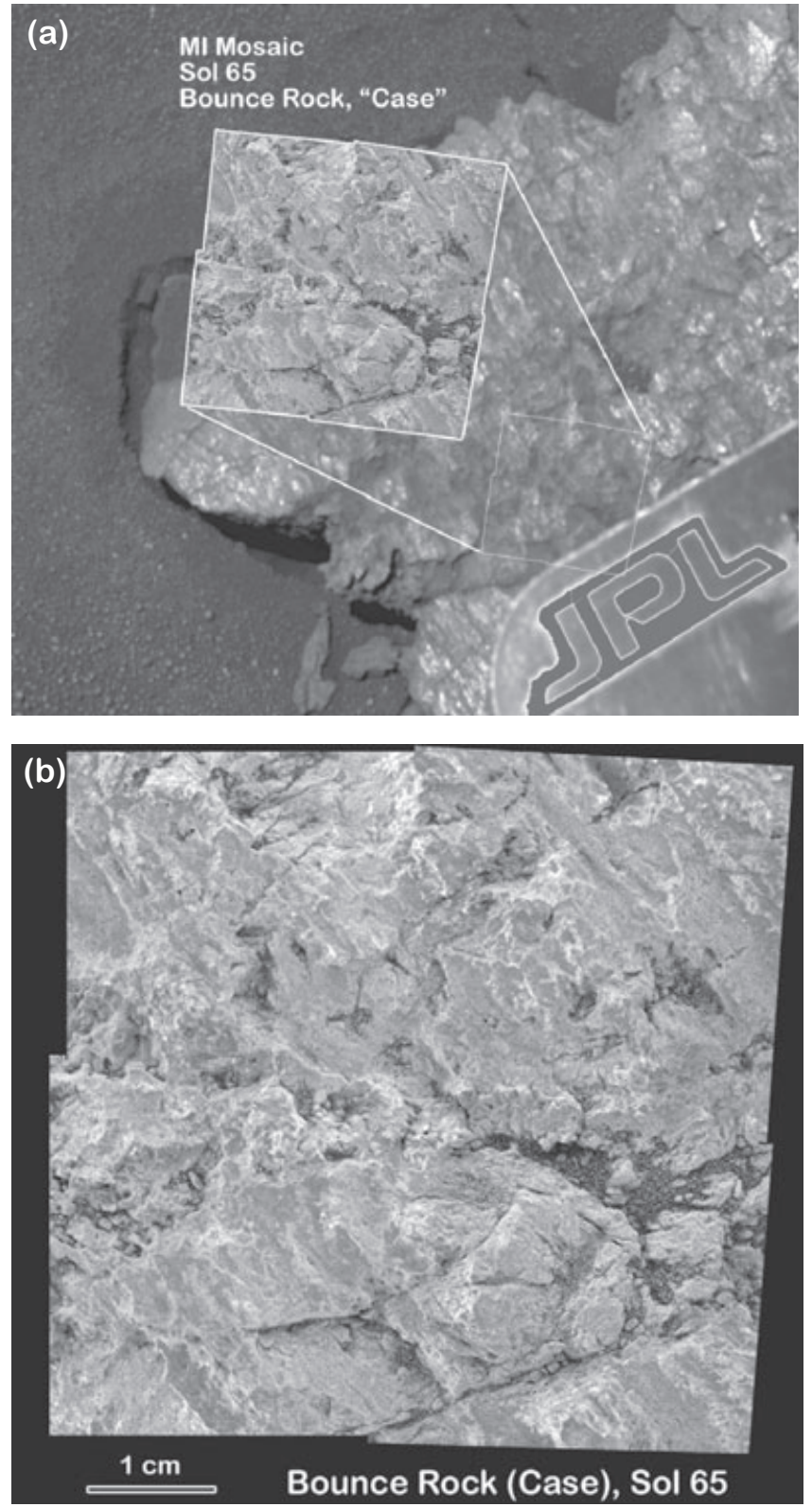

Fig. 3. Same Pancam image as in Fig. 2c. a) Position of target Case as documented by the MI on the pre-RAT surface. b) Details of the pre-RAT MI mosaic of Case. Fractures are partly filled with loose material.

rock surface and the RAT hole were documented with the MI (Figs. 3-5).

When the RAT was used to grind into Bounce Rock, the measured SGE was 3.7 joules per cubic mm, which is significantly less energy than required for typical basalts at Gusev crater $\left(51-83 \mathrm{~J} \mathrm{~mm}^{-3}\right.$; see Arvidson et al. 2004). The RAT was set to a typical preload force of $60 \mathrm{~N}$ and it took $2 \mathrm{~h}$ and $17 \mathrm{~min}$ to grind a $4.5 \mathrm{~cm}$ diameter and $6.4 \mathrm{~mm}$ deep hole (target "Case"; see Figs. 6 and 7). 

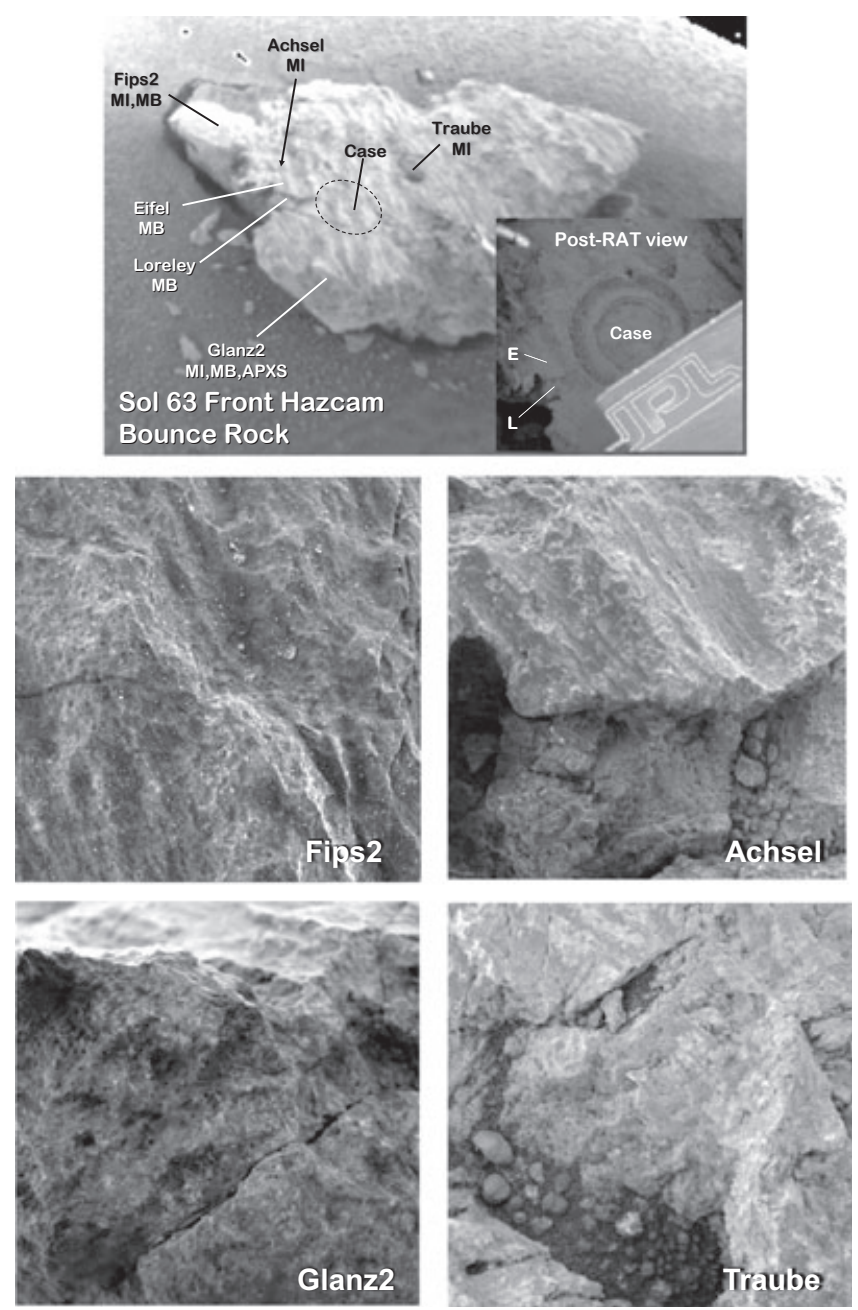

Fig. 4. Sol 63 Front Hazcam image showing locations of preRAT targets and rover arm instrument(s), MI, MB, and APXS used to study the rock at these targets. MI single frames $(3.2 \times 3.2 \mathrm{~cm})$ show details of Bounce Rock's surface texture.

The RAT-abraded surface shows bright features and reveals the interior texture of target Case to be finegrained and crosscut by $\mathrm{mm}$ - to $\mathrm{cm}$-sized fractures. For comparison, inspection of the unpolished sample of basaltic shergottite EETA79001 lithology B with the optical microscope reveals the fine-grained, subophitic texture typical for this meteorite (Steele and Smith 1982) (Fig. 7).

\section{Bulk Chemistry}

The APXS analyzed the chemical composition of two natural surface targets, Maggie and Glanz2, and the abraded target, Case (Figs. 4 and 5). The X-ray spectrum of Case is shown in Fig. 8. Refinements in instrument calibration lead to slightly different results
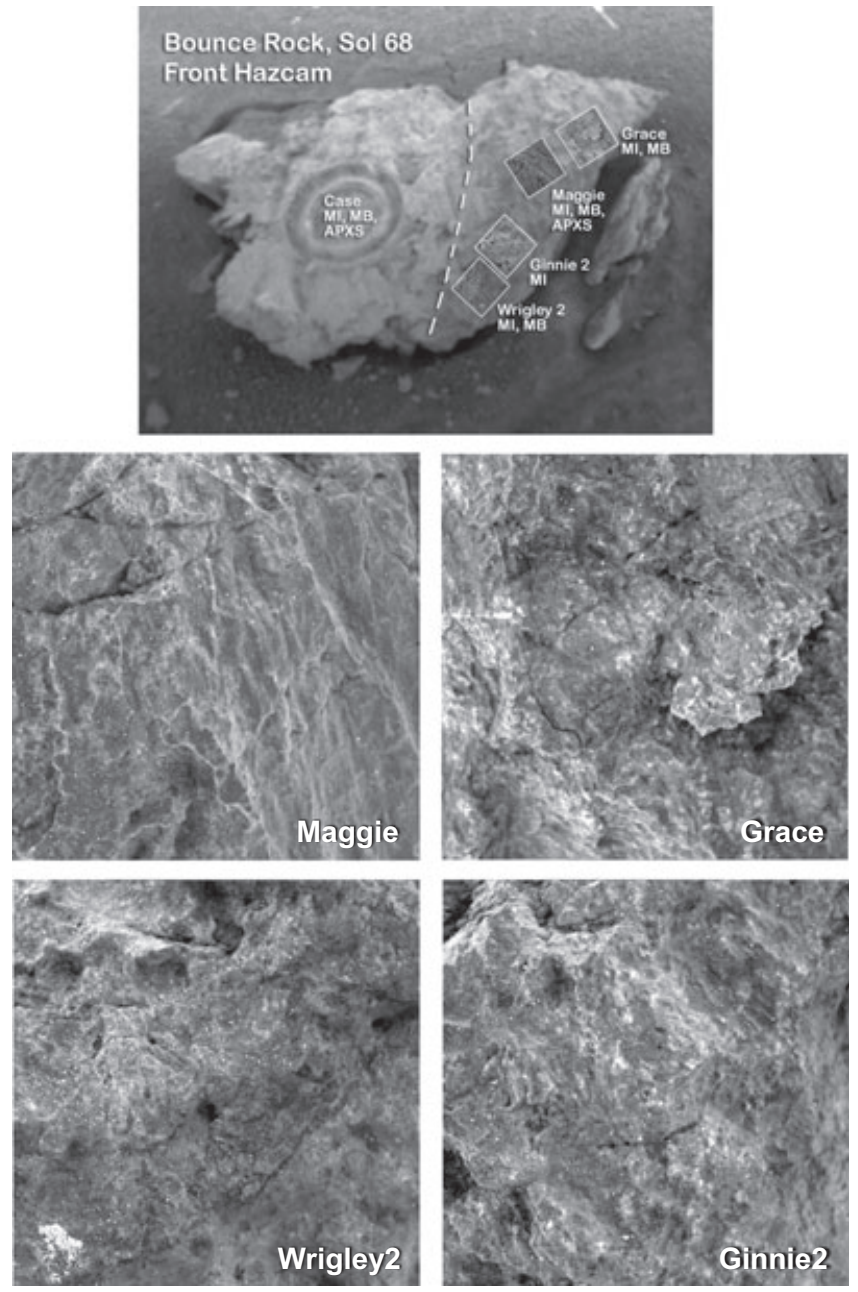

Fig. 5. Sol 68 Front Hazcam image of post-RAT targets. Target locations and approximate orientations to the right of the dashed line (limit of RAT "tailings") are shown. MI single frames $(3.2 \times 3.2 \mathrm{~cm})$ show details of Bounce Rock's surface texture.

from those published earlier (Rieder et al. 2004; Zipfel et al. 2004) and are listed in Table 1.

A comparison of published data with results from APXS analyses of a powdered aliquot of the Martian meteorite Zagami are presented in Table 1 and Fig. 9. The APXS results are, for most elements, in excellent agreement with published data (Banin et al. 1992; Lodders 1998), within calibration accuracy. Larger deviations for $\mathrm{Cl}$ and $\mathrm{K}$ (only upper limits are given), and $\mathrm{Na}, \mathrm{P}, \mathrm{S}$, and Ni probably reflect sample heterogeneity because no systematic deviations in the abundance of these particular elements are observed if results for other rock standards are compared (Gellert et al. 2006).

Alpha Particle X-ray Spectrometer surface analyses of Maggie and Glanz2 show that Bounce Rock is covered by soil/dust. Elements typically enriched in soil (e.g., S, Cl, and Zn; Rieder et al. 2004; Gellert et al. 


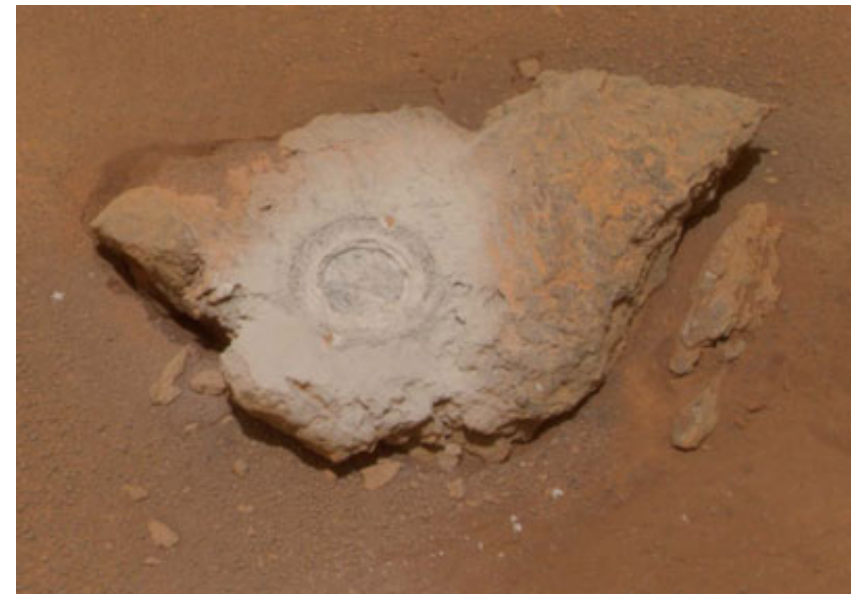

Fig. 6. Pancam "true color" (Savransky and Bell 2004; Bell et al. 2006) image of Bounce Rock, Sol 068 P2581, after the target "Case" was ground with the rock abrasion tool. Unlike the Meridiani outcrop rocks, the grinding dust from Bounce Rock appears white, not red, consistent with an unoxidized, primary silicate interior. Image source is http:// marswatch.astro.cornell.edu/pancam_instrument/images/True/ Sol068B_P2581_1_True_RAD.jpg.

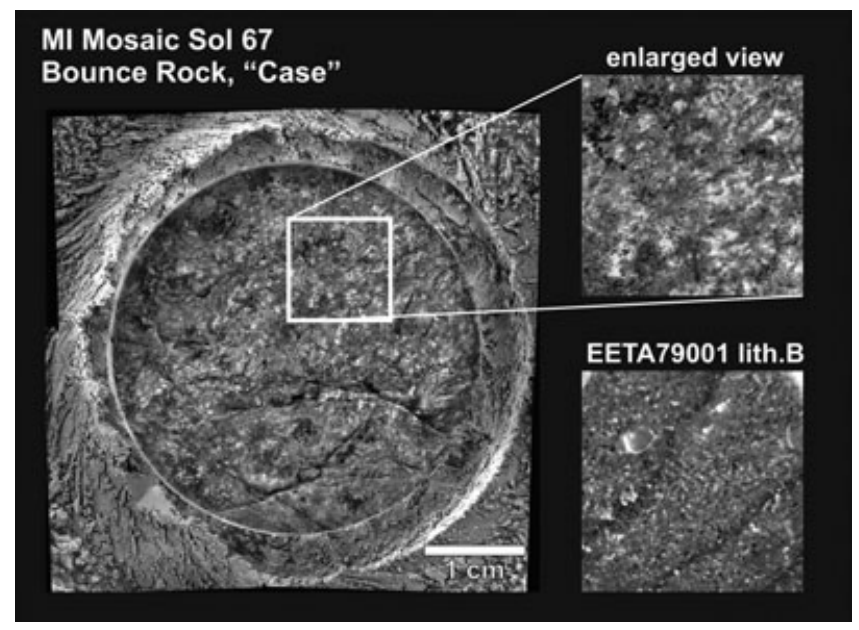

Fig. 7. MI mosaic of post-RAT target Case. The RAT hole $(4.5 \mathrm{~cm}$ across) shows that the rock interior is crosscut by a number of open fractures. Bright features indicate a very weak preferred orientation running "NNE to SSW" relative to the image frame. An enlarged area is shown in direct comparison to the texture of EETA79001 (both areas are $1 \times 1 \mathrm{~cm}$ ).

2006) are significantly higher than for the abraded target Case. Surface concentrations of $\mathrm{S}$, for example, are 1.47 and $1.85 \mathrm{wt} \%$, but only $0.22 \mathrm{wt} \%$ in the interior of the rock. Depletions of $\mathrm{S}, \mathrm{Cl}$, and $\mathrm{Zn}$ in the analysis of Case are compensated mostly by an increase in $\mathrm{SiO}_{2}$ and $\mathrm{CaO}$. Other major and minor element concentrations show only small differences between rock surfaces and interiors, indicating that the surface alteration is minor. Because of large uncertainties,

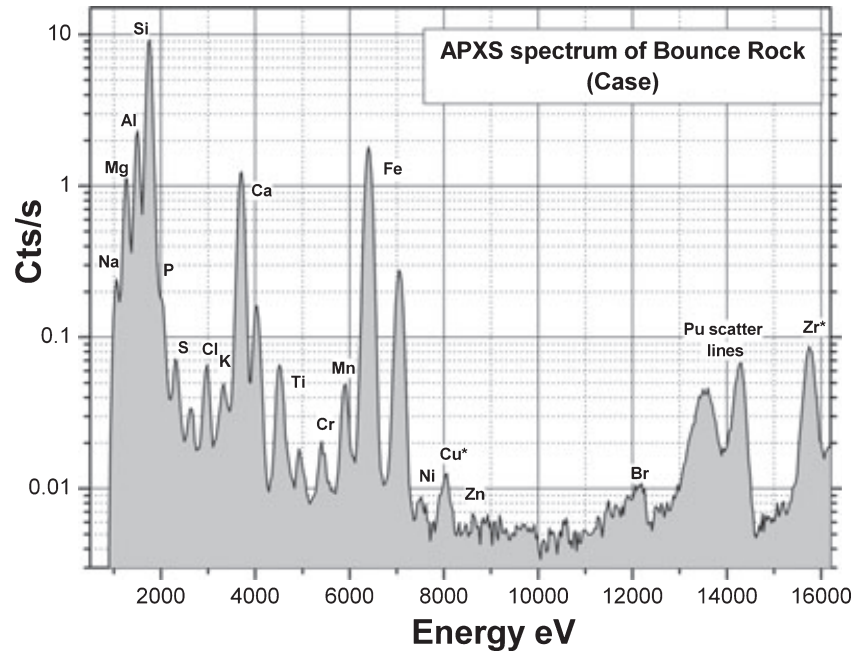

Fig. 8. APXS spectrum of post-RAT target Case measured on Mars by the flight instrument on Opportunity. Peaks from $\mathrm{Cu}$ and $\mathrm{Zr}$ are background peaks from the instrument doors and casing. The apparently high Ni peak is a background artifact.

concentrations of $\mathrm{K}, \mathrm{Ni}$, and $\mathrm{Br}$ do not warrant further characterization of the surface alteration.

The bulk composition of Case has $\mathrm{SiO}_{2}$ of $51.6 \mathrm{wt} \%$ and $\mathrm{Na}_{2} \mathrm{O}$ of $1.7 \mathrm{wt} \%$, and plots in the compositional field of basalts from Earth, on the basis of the alkali versus $\mathrm{SiO}_{2}$ contents, as defined by Le Bas et al. (1986). Concentrations of $\mathrm{Al}_{2} \mathrm{O}_{3}$ and $\mathrm{CaO}$ are relatively high, at 10.5 and $12.1 \mathrm{wt} \%$, respectively.

\section{Mineralogy}

Pancam observations of Case reveal spectral characteristics from 750 to $1000 \mathrm{~nm}$ that are consistent with the presence of pyroxene or olivine (Bell et al. 2004). The Mini-TES obtained spectra from the rock, itself, and some adjacent soil. Christensen et al. (2004) evaluated "dust-removed" spectra, subtracting TES spectra of surface fines from high-albedo regions. The resulting spectrum is consistent with a rock that has a pyroxene-rich mineral assemblage. Deconvolution of this spectrum yields modal mineralogy as follows: clinopyroxene $\quad(\sim 55 \%)$, orthopyroxene $\quad(\sim 5 \%)$, plagioclase $(\sim 20 \%)$, olivine $(\sim 5 \%)$, and oxides $(\sim 10 \%)$ (Christensen et al. 2004).

Mössbauer spectra from Case, and seven additional targets on the natural surface of the rock were acquired (Glanz2, Eifel, Loreley, Fips2, Grace, Wrigley2, and Maggie; see Figs. 4 and 5). All $\mathrm{Fe}^{2+}$ is hosted in highand low-Ca pyroxenes (Klingelhöfer et al. 2004; Morris et al. 2006b). Table 2 shows results from MB spectra obtained at two different energies, 6 and $14 \mathrm{keV}$. The higher-energy spectra penetrate deeper into the rock 
Table 1. Composition of Bounce Rock and selected basaltic shergottites (wt \%).

\begin{tabular}{|c|c|c|c|c|c|c|c|c|c|}
\hline & \multicolumn{4}{|c|}{ Bounce Rock } & EETA79001 ${ }^{\mathrm{b}}$ & \multirow[b]{2}{*}{$\begin{array}{l}\text { QUE } \\
94201^{\mathrm{b}}\end{array}$} & \multirow[b]{2}{*}{ Zagami $^{\mathrm{c}}$} & \multirow[b]{2}{*}{ Zagami $^{\text {b }}$} & \multirow[b]{2}{*}{ Shergotty } \\
\hline & $\begin{array}{l}\text { SD } \\
\%{ }^{a}\end{array}$ & $\begin{array}{l}\text { Maggie } \\
\text { (surface) }\end{array}$ & $\begin{array}{l}\text { Glanz2 } \\
\text { (surface) }\end{array}$ & $\begin{array}{l}\text { Case } \\
\text { (interior) }\end{array}$ & Lithology B & & & & \\
\hline \multicolumn{10}{|l|}{$(w t \%)$} \\
\hline $\mathrm{SiO}_{2}$ & 3.5 & 47.5 & 48.5 & 51.6 & 49.4 & 47.9 & 50.8 & 50.5 & 51.3 \\
\hline $\mathrm{TiO}_{2}$ & 20 & 0.69 & 0.83 & 0.74 & 1.18 & 1.84 & 0.96 & 0.79 & 0.82 \\
\hline $\mathrm{Al}_{2} \mathrm{O}_{3}$ & 7 & 10.7 & 9.7 & 10.5 & 11.2 & 11 & 5.7 & 6.05 & 6.88 \\
\hline $\mathrm{Cr}_{2} \mathrm{O}_{3}$ & 20 & 0.12 & 0.10 & 0.11 & 0.17 & 0.14 & 0.33 & 0.33 & 0.20 \\
\hline $\mathrm{FeO}$ & 6 & 14.2 & 15.5 & 14.4 & 17.4 & 18.5 & 17.7 & 18.1 & 19.4 \\
\hline $\mathrm{MnO}$ & 8 & 0.37 & 0.42 & 0.40 & 0.43 & 0.45 & 0.52 & 0.5 & 0.52 \\
\hline $\mathrm{CaO}$ & 8 & 9.8 & 10.9 & 12.1 & 10.8 & 11.4 & 11.2 & 10.5 & 9.6 \\
\hline $\mathrm{MgO}$ & 17 & 7.7 & 6.6 & 6.8 & 6.57 & 6.25 & 10.2 & 11.3 & 9.3 \\
\hline $\mathrm{Na}_{2} \mathrm{O}$ & 8.5 & 2.2 & 2.0 & 1.7 & 1.74 & 1.58 & 1.3 & 1.23 & 1.39 \\
\hline $\mathrm{K}_{2} \mathrm{O}$ & 15 & $0.3(1)$ & $0.3(1)$ & $0.1(1)$ & 0.075 & 0.045 & $<0.10$ & 0.14 & 0.17 \\
\hline $\mathrm{P}_{2} \mathrm{O}_{5}$ & 17 & 0.88 & 0.99 & 0.92 & 1.28 & & 0.82 & 0.5 & 0.67 \\
\hline Sum $^{\mathrm{d}}$ & & 100.0 & 99.9 & 100.0 & 100.2 & 99.1 & 100.0 & 99.9 & 100.3 \\
\hline $\mathrm{S}$ & 15 & 1.85 & 1.47 & 0.22 & 0.193 & & 0.15 & 0.19 & 0.323 \\
\hline $\mathrm{Cl}$ & 12 & 0.94 & 0.57 & 0.10 & 0.0048 & 0.0091 & $<0.03$ & 0.0137 & 0.0108 \\
\hline \multicolumn{10}{|l|}{ (ppm) } \\
\hline $\mathrm{Ni}^{\mathrm{e}}$ & 20 & $160(40)$ & $150(60)$ & $80(40)$ & 28 & $<20$ & $110(10)$ & 48 & 79 \\
\hline $\mathrm{Zn}$ & 12 & $145(15)$ & $110(30)$ & $40(20)$ & 91 & 110 & $60(10)$ & 60 & 69 \\
\hline $\mathrm{Br}$ & & $<40$ & $<40$ & $<40$ & 0.025 & 0.35 & $<10$ & 0.83 & 0.88 \\
\hline $\begin{array}{l}\text { Molar } \\
(\mathrm{MgO} /[\mathrm{MgO}+\mathrm{FeO}])\end{array}$ & & 0.49 & 0.43 & 0.46 & 0.40 & 0.38 & 0.51 & 0.53 & 0.46 \\
\hline $\mathrm{Ca} / \mathrm{Al} \mathrm{wt}^{2} \%$ & & 1.24 & 1.52 & 1.56 & 1.30 & 1.40 & 2.63 & 2.34 & 1.88 \\
\hline $\mathrm{Fe} / \mathrm{Mn} \mathrm{wt} \%$ & & 38.5 & 37.0 & 36.1 & 40.6 & 41.3 & 34.3 & 36.3 & 37.4 \\
\hline
\end{tabular}

Note: < = Upper limit.

${ }^{a}$ Average deviation from certified value in percent during calibration (Gellert et al. 2006). If statistical error is larger than this standard deviation, the absolute statistical error is shown in brackets.

${ }^{\mathrm{b}}$ Data from Lodders (1998).

${ }^{\mathrm{c}}$ Result of APXS analyses with flight spare instrument (BB10).

${ }^{\mathrm{d}}$ Totals of APXS analyses include sulfur as $\mathrm{SO}_{3}$ in $\mathrm{wt} \%$.

${ }^{\mathrm{e}} \mathrm{Ni}$ in Bounce Rock corrected for background in the Opportunity flight instrument.

(Klingelhöfer et al. 2003; Fleischer et al. 2008) and differences in $\mathrm{Fe}^{3+}$ abundances may be attributed to surface alteration. The highest amounts of a ferric phase define the upper limit for iron oxides to be $10 \%$ of total $\mathrm{Fe}$ (Table 2). Features characteristic of olivine were not observed in any of the Bounce Rock spectra. In the MB spectrum of EETA79001 lithology B, all $\mathrm{Fe}^{2+}$ is hosted in pyroxenes. No other Fe-bearing phases were detected (Table 4). As support for the pyroxene-rich spectral observations, mineral norm calculations from the APXS data for Case give a pyroxene-normative composition (Table 3).

\section{DISCUSSION}

\section{Texture}

Herkenhoff et al. (2004) originally interpreted striations observed on the surface of Bounce Rock to be similar in appearance to slickensides formed by differential motion under pressure in terrestrial rocks.
However, when inspecting detailed MI images, these striations are also reminiscent of those of shatter cones (Fig. 10). Gibson and Spray (1998) and Nicolaysen and Reimold (1999) describe similar features in shatter cones from Sudbury and Vredefort impact structures, respectively. Striations on shatter-cone surfaces are fractures that may be divergent or subparallel, to almost parallel. They are generally thought to be caused by shock waves during the compression stage of impact. However, it has also been proposed that shatter cones are tensile fractures forming immediately after the passage of the shock wave through the target rock and during shock unloading (Wieland et al. 2006). The relative weakness of Bounce Rock in comparison to weathered basaltic rocks studied in the Gusev plains is possibly also the result of impact-produced fracturing. Alternatively, wind erosion could have sculpted Bounce Rock's surface with striation-like features.

The exposed interior of Bounce Rock, as seen in a mosaic of MI images of Case, shows a fine-grained, fractured texture unlike that of a sedimentary rock, 


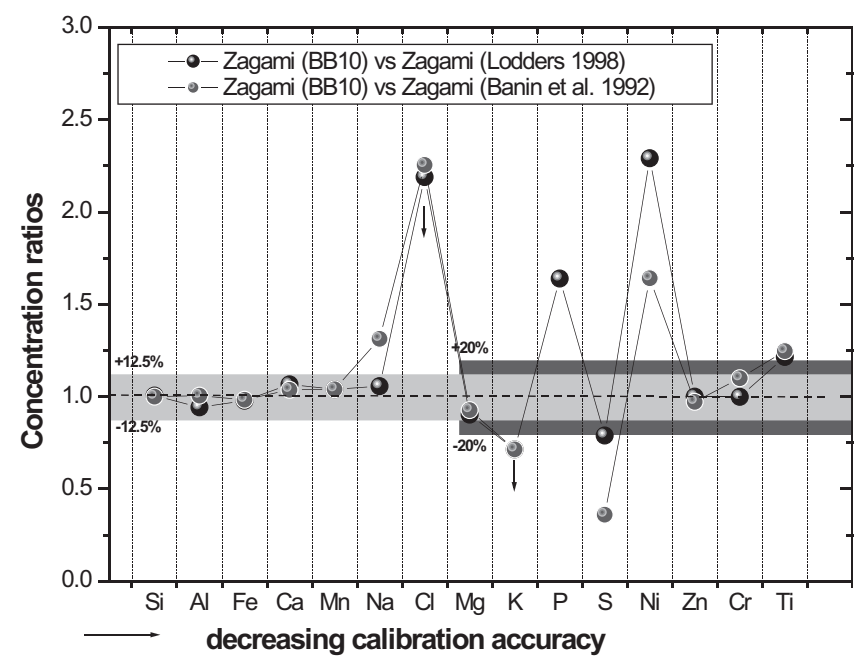

Fig. 9. Comparison of APXS results and published data. A powder aliquot of Zagami was analyzed in the laboratory with an APXS flight spare instrument (BB10). The agreement for major and some minor elements is excellent and well within the calibration uncertainties. Larger discrepancies as observed for $\mathrm{P}, \mathrm{S}$, and Ni probably reflect sample heterogeneity. Arrows at $\mathrm{Cl}$ and $\mathrm{K}$ indicate upper limits for these elements in the Zagami (BB10) analyses.

although brighter features indicate a weak preferred orientation. Herkenhoff et al. (2004) noted a hint of a brecciated texture. Results from our study indicate a texture similar to that of igneous rocks that may be comparable to Martian meteorites. An enlarged area $1 \mathrm{~cm}$ across allows direct comparison to an unpolished sample of EETA79001 of lithology B (Fig. 7). EETA79001 is the only Martian meteorite recovered so far that contains two igneous lithologies separated along a gradational, unbrecciated contact (e.g., Steele and Smith 1982). The mineralogy of lithology A and B is similar, but lithology $\mathrm{A}$ is slightly finer grained $(<0.3 \mathrm{~mm})$ and contains megacrysts of olivine (e.g., McSween and Treiman 1998 and references therein). Like other basaltic shergottites both lithologies have a subophitic texture consisting of laths of pyroxenes, augite, and pigeonite, and interstitial maskelynite, a diapletic glass formed from plagioclase under high shock pressures (e.g., Milton and De Carli 1963). Although there are discernable lath-shaped crystals, a similar texture in Bounce Rock is difficult to resolve but cannot be excluded. Bounce Rock may be finer grained or it has obscured grain boundaries from either shock fracturing or adhering dust from the RAT abrasion.

\section{Bulk Composition}

Concentrations of most elements in the abraded rock target (Case) agree within the limits of calibration accuracy of $12.5-20 \mathrm{rel} \%$ or better with the compositions of two basaltic shergottites, lithology B of EETA79001 and Queen Alexandra Range (QUE) 94201 (Fig. 11 and Table 1). A high $\mathrm{Cl}$ concentration in Bounce Rock could imply that minor alteration products are present even in the rock's interior, possibly concentrated along fractures. Lower $\mathrm{TiO}_{2}, \mathrm{FeO}$, and $\mathrm{Cr}_{2} \mathrm{O}_{3}$ concentrations than typical for basaltic shergottites indicate a relatively low content of minor opaque phases, such as ilmenite and ulvöspinel (see also mineralogy discussion of $\mathrm{MB}$ results).

Basaltic shergottites span a wide range in composition, with $\mathrm{MgO}$ ranging from 4 to $11.5 \mathrm{wt} \%$. Compositional trends of decreasing $\mathrm{Al}_{2} \mathrm{O}_{3}, \mathrm{CaO}$, and $\mathrm{P}_{2} \mathrm{O}_{5}$ and increasing $\mathrm{Cr}_{2} \mathrm{O}_{3}$ with increasing $\mathrm{MgO}$ exist for these meteorites and are indicated by the linear regression lines in Fig. 11. All three Bounce Rock analyses fall on - or plot close to - these trend lines at $\mathrm{MgO}$ concentrations varying from 6.6 to $7.7 \mathrm{wt} \%$.

Other rocks analyzed on Mars deviate significantly from these trends. Pathfinder soil-free rock, which has a basaltic-andesite-like composition (Brückner et al. 2003; Foley et al. 2003), falls considerably off these trends, with very low $\mathrm{MgO}$. It should be noted that this Pathfinder rock composition was derived from surface analyses after subtracting contributions from adhering soil. Gusev basalts, especially the Adirondack-class basalts, which are close to picritic basalts in composition and are olivine-rich (Gellert et al. 2004; McSween et al. 2004, 2006), plot on the high-MgO side. In the Gusev basalts, concentrations of $\mathrm{P}_{2} \mathrm{O}_{5}$ fall on the trend line, those of $\mathrm{Al}_{2} \mathrm{O}_{3}$ and $\mathrm{Cr}_{2} \mathrm{O}_{3}$ plot significantly above the trend, and those of $\mathrm{CaO}$ plot significantly below the trend. Rocks of other basaltic classes analyzed in Gusev Crater, such as Irvine or Backstay, also deviate from the compositional trends defined by Martian meteorites (e.g., McSween et al. 2009). The sulfur-rich sedimentary rocks from Meridiani Planum (Rieder et al. 2004) have significantly lower $\mathrm{CaO}$ concentrations than basaltic shergottites and even Gusev basalts (Gellert et al. 2004). None of these rocks have chemical similarities to other subgroups of Martian meteorites (e.g., olivine-phyric and lherzolitic shergottites, nakhlites, chassignites, and the orthopyroxenite ALH 84001). Therefore, Bounce Rock is exceptional; compared to all other rocks analyzed on Mars to date, it is the only rock with a chemical composition that is similar enough to those of two Martian meteorites to permit unambiguous classification as one of them.

\section{Mineral Composition}

Studies with the Pancam, Mini-TES, MB, and APXS consistently show that Bounce Rock has a mineralogy 
Table 2. Mössbauer parameters from 6.4 and $14.4 \mathrm{keV}$ spectra of Bounce Rock summed over all temperature windows.

\begin{tabular}{|c|c|c|c|c|c|c|c|c|c|c|c|}
\hline & \multicolumn{5}{|c|}{ PxM1 } & \multicolumn{3}{|l|}{ PxM2 } & \multicolumn{3}{|l|}{ npOx } \\
\hline & $\begin{array}{l}T \\
(\mathrm{~K})\end{array}$ & $(\mathrm{kEV})$ & $\begin{array}{l}\delta^{\mathrm{a}} \\
\left(\mathrm{mm} \mathrm{s}^{-1}\right)\end{array}$ & $\begin{array}{l}\Delta E_{\mathrm{Q}}^{\mathrm{b}} \\
\left(\mathrm{mm} \mathrm{s}^{-1}\right)\end{array}$ & $\begin{array}{l}A^{\mathrm{c}} \\
(\%) \\
\end{array}$ & $\begin{array}{l}\delta \\
\left(\mathrm{mm} \mathrm{s}^{-1}\right)\end{array}$ & $\begin{array}{l}\Delta E_{\mathrm{Q}} \\
\left(\mathrm{mm} \mathrm{s}^{-1}\right)\end{array}$ & $\begin{array}{l}A \\
(\%) \\
\end{array}$ & $\begin{array}{l}\delta \\
\left(\mathrm{mm} \mathrm{s}^{-1}\right)\end{array}$ & $\begin{array}{l}\Delta E_{\mathrm{Q}} \\
\left(\mathrm{mm} \mathrm{s}^{-1}\right)\end{array}$ & $\begin{array}{l}A \\
(\%) \\
\end{array}$ \\
\hline \multirow[t]{2}{*}{ Glanz2 } & $200-260$ & 14.4 & 1.16 & 2.75 & 69 & 1.13 & 2.04 & 29 & {$[0.47]$} & {$[0.67]$} & 2 \\
\hline & & 6.4 & 1.17 & 2.75 & 68 & 1.14 & 2.04 & 28 & {$[0.47]$} & {$[0.67]$} & 3 \\
\hline \multirow[t]{2}{*}{ Case } & $200-260$ & 14.4 & 1.17 & 2.76 & 73 & 1.14 & 2.05 & 27 & {$[0.47]$} & {$[0.67]$} & 1 \\
\hline & & 6.4 & 1.18 & 2.77 & 75 & 1.15 & 2.07 & 24 & {$[0.47]$} & {$[0.67]$} & 1 \\
\hline \multirow[t]{2}{*}{ Eifel } & $250-260$ & 14.4 & 1.20 & 2.74 & 65 & 1.16 & 2.01 & 31 & {$[0.47]$} & {$[0.67]$} & 3 \\
\hline & & 6.4 & [1.20] & [2.74] & 77 & [1.16] & [2.01] & 21 & {$[0.47]$} & {$[0.67]$} & 2 \\
\hline \multirow[t]{2}{*}{ Loreley } & $250-260$ & 14.4 & 1.18 & 2.76 & 71 & 1.15 & 2.03 & 29 & {$[0.47]$} & {$[0.67]$} & 0 \\
\hline & & 6.4 & [1.18] & [2.76] & 69 & [1.15] & [2.03] & 28 & {$[0.47]$} & {$[0.67]$} & 3 \\
\hline \multirow[t]{2}{*}{ Fips2 } & $200-250$ & 14.4 & 1.16 & 2.76 & 66 & 1.14 & 2.05 & 31 & {$[0.47]$} & {$[0.67]$} & 3 \\
\hline & & 6.4 & 1.16 & 2.85 & 75 & 1.15 & 2.11 & 20 & {$[0.47]$} & {$[0.67]$} & 5 \\
\hline \multirow[t]{2}{*}{ Grace } & $240-260$ & 14.4 & 1.17 & 2.72 & 74 & 1.15 & 2.08 & 23 & {$[0.47]$} & {$[0.67]$} & 3 \\
\hline & & 6.4 & [1.17] & {$[2.72]$} & 75 & [1.15] & [2.08] & 20 & {$[0.47]$} & {$[0.67]$} & 5 \\
\hline \multirow[t]{2}{*}{ Wrigley2 } & $250-260$ & 14.4 & 1.17 & 2.70 & 63 & 1.15 & 2.01 & 32 & {$[0.47]$} & {$[0.67]$} & 5 \\
\hline & & 6.4 & [1.17] & {$[2.70]$} & 64 & [1.15] & {$[2.01]$} & 35 & {$[0.47]$} & {$[0.67]$} & 2 \\
\hline \multirow{2}{*}{$\begin{array}{r}\text { Maggie } \\
{\text { (red. })^{\mathrm{d}}}^{\text {Mand }}\end{array}$} & $200-250$ & 14.4 & 1.17 & 2.78 & 70 & 1.14 & 2.07 & 25 & 0.47 & 0.67 & 4 \\
\hline & & 6.4 & 1.17 & 2.78 & 67 & 1.15 & 2.08 & 24 & {$[0.47]$} & {$[0.67]$} & 8 \\
\hline \multirow{2}{*}{$\begin{array}{l}\text { Maggie } \\
\text { (full) }^{\mathrm{e}}\end{array}$} & $200-210$ & 14.4 & 1.16 & 2.82 & 73 & 1.13 & 2.07 & 24 & {$[0.47]$} & {$[0.67]$} & 3 \\
\hline & & 6.4 & 1.19 & 2.75 & 66 & 1.16 & 2.11 & 24 & {$[0.47]$} & {$[0.67]$} & 10 \\
\hline
\end{tabular}

Note: Values in square brackets were fixed during fitting procedure.

${ }^{\mathrm{a}}$ Center shift, relative to $\alpha$-Fe. Uncertainty is $\pm 0.02 \mathrm{~mm} \mathrm{~s}^{-1}$.

${ }^{\mathrm{b}}$ Quadrupole splitting. Uncertainty is $\pm 0.02 \mathrm{~mm} \mathrm{~s}^{-1}$.

${ }^{c}$ Relative subspectral area, $f$-factor corrected with $f\left(\mathrm{Fe}^{3+}\right) / f\left(\mathrm{Fe}^{2+}\right)=1.21$ (cf. Morris et al. 2006b). Uncertainty is $\pm 2 \%$.

${ }^{\mathrm{d}}$ Maggie (red.) spectrum obtained with reduced maximum drive velocity, approximately $4 \mathrm{~mm} \mathrm{~s}^{-1}$.

${ }^{\mathrm{e}}$ Maggie (full) spectrum obtained at full standard maximum drive velocity, approximately $12 \mathrm{~mm} \mathrm{~s}^{-1}$.

Table 3. Calculated normative mineralogy and plagioclase composition $(\mathrm{wt} \%)^{\mathrm{a}}$.

\begin{tabular}{|c|c|c|c|c|c|}
\hline & $\begin{array}{l}\text { Bounce Rock } \\
\text { Case }\end{array}$ & $\frac{\text { EETA79001 }^{\mathrm{b}}}{\text { Lithology B }^{-}}$ & QUE $94201^{\mathrm{b}}$ & Zagami $^{\text {b }}$ & Shergotty \\
\hline Ilmenite & 1.4 & 2.2 & 3.5 & 1.5 & 1.6 \\
\hline Chromite & 0.2 & 0.3 & 0.2 & 0.5 & 0.3 \\
\hline Apatite & 2.2 & 3.0 & n.d. & 1.2 & 1.6 \\
\hline Orthoclase & & 0.4 & 0.3 & 0.8 & 1.0 \\
\hline Albite & 14.6 & 15.3 & 14.0 & 10.7 & 12.1 \\
\hline Anorthite & 20.9 & 22.0 & 22.3 & 10.3 & 11.7 \\
\hline Diopside & 27.8 & 19.1 & 28.9 & 31.9 & 26.2 \\
\hline Hypersthene & 29.2 & 32.6 & 23.5 & 38.7 & 45.1 \\
\hline Olivine & 0 & 0 & 7.0 & 4.8 & 0 \\
\hline Quartz & 3.9 & 0.6 & 0 & 0 & 0.8 \\
\hline Plagioclase $_{\mathrm{An}}$ & 58.8 & 59.0 & 61.6 & 49.0 & 49.1 \\
\hline
\end{tabular}

Note: n.d. $=$ not detected.

${ }^{\mathrm{a}}$ For calculation of the norm it was assumed that bulk compositions are $\mathrm{S}$ - and $\mathrm{Cl}$-free and that all $\mathrm{Fe}$ is $\mathrm{Fe}^{2+}$.

${ }^{\mathrm{b}}$ Calculated from compositions given by Lodders (1998).

dominated by pyroxene. The mineralogy derived from deconvolution of a Mini-TES spectrum shows that Bounce Rock contains about three times more pyroxene, mostly clinopyroxene, than plagioclase (Christensen et al. 2004). This composition is unlike that of any other igneous rock analyzed by Mini-TES on Mars, but similar to Martian meteorites.
The iron-bearing mineralogy of Bounce Rock is determined by MB spectroscopy. Spectra are dominated by features consistent with pyroxenes; olivine was not identified in any of the MB spectra. Given the presence of Fe-bearing pyroxene, we argue that coexisting forsterite (the Fe-free olivine endmember), which would not be detected by MB, can be excluded. Therefore, 


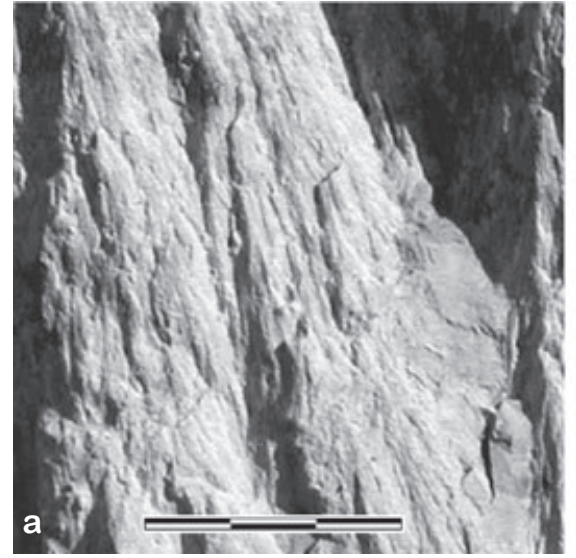

Piece of shatter cone, Kentland, Indiana
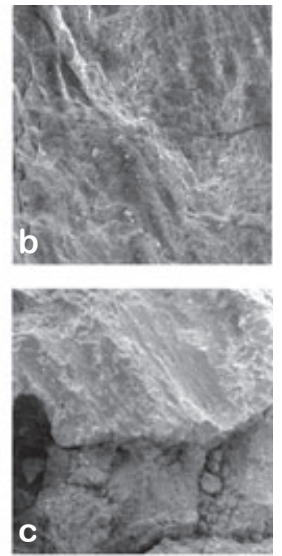

Bounce Rock Meridiani Planum
Fig. 10. Bounce Rock surface textures compared to texture of a rock from a terrestrial impact structure exhibiting shattercone texture. The surface of Bounce Rock appears fragile as it shows loose material and many fractures. a) Shatter cone from Kentland impact structure, Indiana (rock is dolomite). Scale bar is $3 \mathrm{~cm}$. Photo of Kentland specimen courtesy of Amir Sagy. b) Bounce Rock (target "Fips") MI image, sol 67, P2956. c) Bounce Rock (target "Achsel") MI image, sol 65, P2956. All three images are shown at approximately the same scale.

fitted olivine in the Mini-TES spectrum may be an artifact of missing endmembers in the spectral library used for deconvolution.

There is no evidence in the various spectra of Bounce Rock for detectable quantities of minor Fe-bearing phases, such as ilmenite, chromite, ulvöspinel, or pyrrhotite, which are typically present in Martian meteorites. Small amounts of $\mathrm{Fe}^{3+}$ in Bounce Rock MB spectra have been noted by Morris et al. (2006b) who interpreted the $\mathrm{Fe}^{3+}$ component as nanophase ferric oxide, which is also identified in surrounding soil and dust. This species is a valid choice because all analyzed natural surfaces, i.e., dust-covered, have higher amounts of $\mathrm{Fe}^{3+}$ than the abraded target Case. However, if the $\mathrm{Fe}^{3+}$ was exclusively from surface dust, it should also show an enhanced abundance in the $6 \mathrm{keV}$ spectra of all natural targets (Table 2). A significant difference was only observed for target Maggie. Therefore, one additional spectrum, Maggie (Maggie [red] in Table 2 and Fig. 12) was obtained at increased resolution (reduced velocity) over the energy range of the pyroxene feature. The MB parameters of the $\mathrm{Fe}^{3+}$ doublet derived from this spectrum differ from those of nanophase ferric oxide reported by Morris et al. (2006b), but are similar to those reported for $\mathrm{Fe}^{3+}$ in whole rock samples and pyroxene separates of Martian meteorites, and basaltic shergottites in particular (Dyar 2003). Therefore, it is also possible that the $\mathrm{Fe}^{3+}$ is inherent to the pyroxene.
Normative mineralogy calculations from APXS bulk chemical data from Case (Table 3) show that Bounce Rock has a pyroxene-normative composition, with $57 \mathrm{wt} \%$ pyroxene distributed in about equal amounts to high-Ca pyroxene (diopside) and low-Ca pyroxene (hypersthene). Plagioclase, calculated as albite and anorthite, sums to about $35.5 \%$. Minor phases include ilmenite, chromite and apatite. Excess $\mathrm{SiO}_{2}$ leads to calculation of free quartz.

Bounce Rock has a mineral norm that agrees well with those of lithology B of EETA79001 and QUE 94201, reflecting its close chemical relationship to these meteorites. Albite and anorthite normative values agree well with these two meteorites and are unlike those calculated for Zagami and Shergotty, two basaltic shergottites with cumulus pyroxene. A major difference, however, is the low abundance of ilmenite (not detected by $\mathrm{MB}$ ), which reflects low $\mathrm{TiO}_{2}$ and $\mathrm{FeO}$ bulk-rock concentrations in Bounce Rock. The higher diopside component, if compared to EETA79001, reflects the high $\mathrm{CaO}$ concentration in Bounce Rock. No normative olivine was calculated, which is also the case for EETA79001 and Shergotty but not for QUE 94201 and Zagami. The reason for the olivine-normative composition of QUE 94201 is the lack of $\mathrm{P}_{2} \mathrm{O}_{5}$ concentrations in published data sets (Lodders 1998). If we assume a $\mathrm{P}_{2} \mathrm{O}_{5}$ concentration of $2 \mathrm{wt} \%$ in QUE 94201 (Mittlefehldt, unpublished data) the mineral norm would be olivine-free (and slightly quartz-normative) because normally $\mathrm{P}$ combines with $\mathrm{Ca}$ in apatite. Without $\mathrm{P}$, the $\mathrm{Ca}$ that would normally be assigned to apatite is assigned to high-Ca pyroxene, which in turn has the effect of reducing the amount of normative hypersthene and increasing the amount of normative olivine.

We emphasize that normative mineralogy calculations mainly are intended to characterize and compare the bulk chemical composition of rocks in terms of a standard set of minerals. The resulting normative mineralogy and mineral proportions do not necessarily reflect the true modal mineralogy of a rock, although they may be similar if the rock is composed of the same mineral assemblage as the standard set of normative minerals.

\section{Pyroxene Mineralogy}

Basaltic shergottites EETA79001 lithology B and QUE 94201 have pyroxene grains with $\mathrm{Mg}$-rich pigeonite cores $\left(\mathrm{En}_{64} \mathrm{Fs}_{26} \mathrm{Wo}_{10}\right.$ and $\mathrm{En}_{62} \mathrm{Fs}_{30} \mathrm{Wo}_{8}$, respectively) mantled by minor $\mathrm{Mg}$-rich augite $\left(\mathrm{En}_{46} \mathrm{Fs}_{22} \mathrm{Wo}_{32}\right.$ and $\mathrm{En}_{44} \mathrm{Fs}_{20} \mathrm{Wo}_{36}$, respectively), and commonly extremely Fe-rich pigeonite rims $\left(\mathrm{En}_{9} \mathrm{Fs}_{76} \mathrm{Wo}_{15}\right.$ and $\mathrm{En}_{5} \mathrm{Fs}_{81} \mathrm{Wo}_{14}$, respectively) (Mikouchi et al. 1999). In Shergotty and Zagami, 


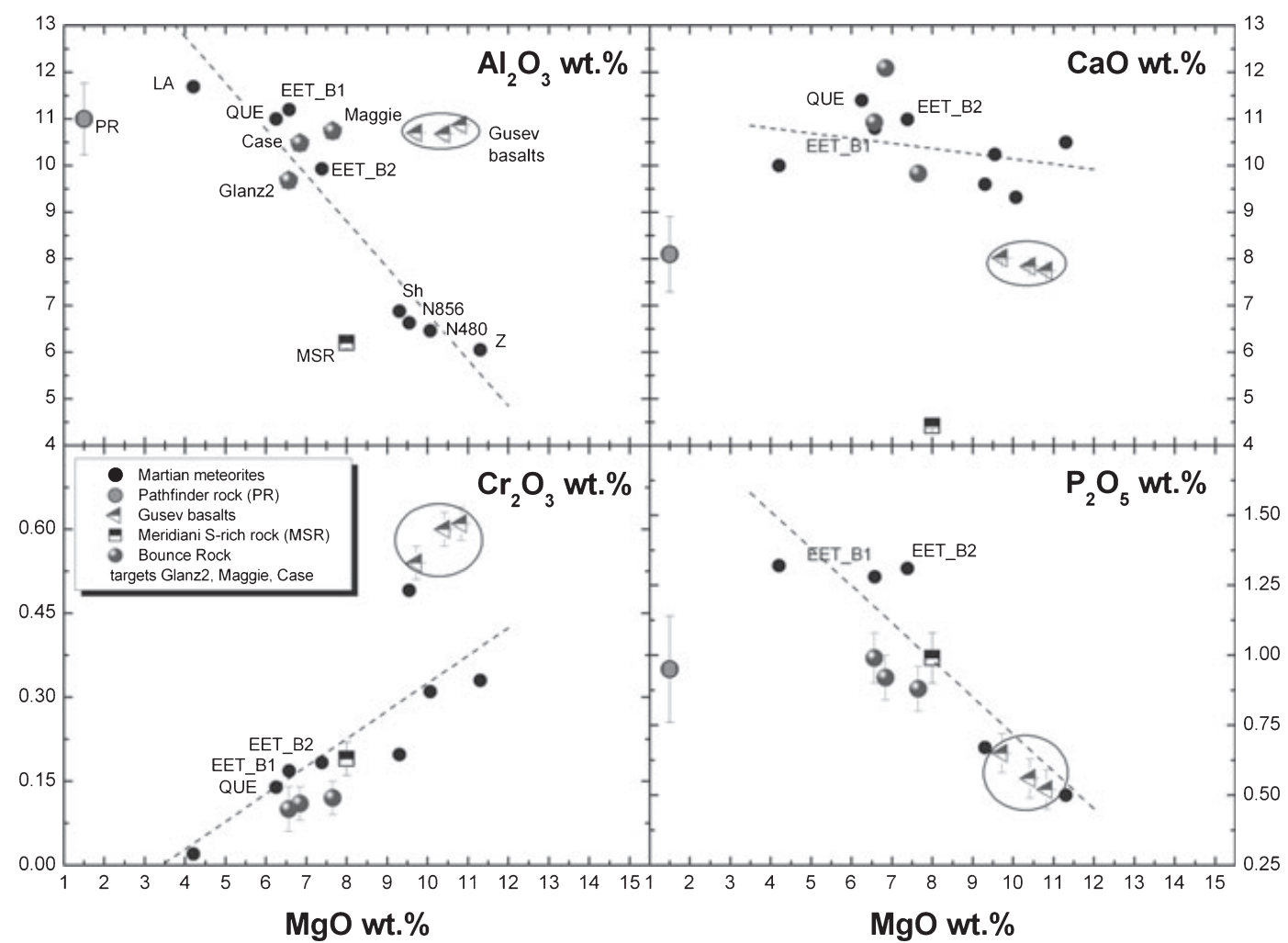

Fig. 11. Element variation diagrams versus $\mathrm{MgO} w \mathrm{t} \%$ of all Bounce Rock analyses and selected basaltic shergottites; LA = Los Angeles (G. Dreibus, unpublished data), QUE = QUE 94201 (Lodders 1998), EETA79001, lithology B = EET_B1 (Lodders 1998) and EET B2 (Banin et al. 1992), Sh = Shergotty (Lodders 1998), N856 = NWA 856 (Jambon et al. 2002), N480 = NWA $4 \overline{80}$ (Barrat et al. 2002), Z = Zagami (Lodders 1998). Trend lines are best-fit lines through basaltic shergottites. For comparison, Pathfinder soil-free rock (Brückner et al. 2003), Gusev basalts (Gellert et al. 2006), and one S-rich rock at Meridiani Planum (Rieder et al. 2004) are shown.

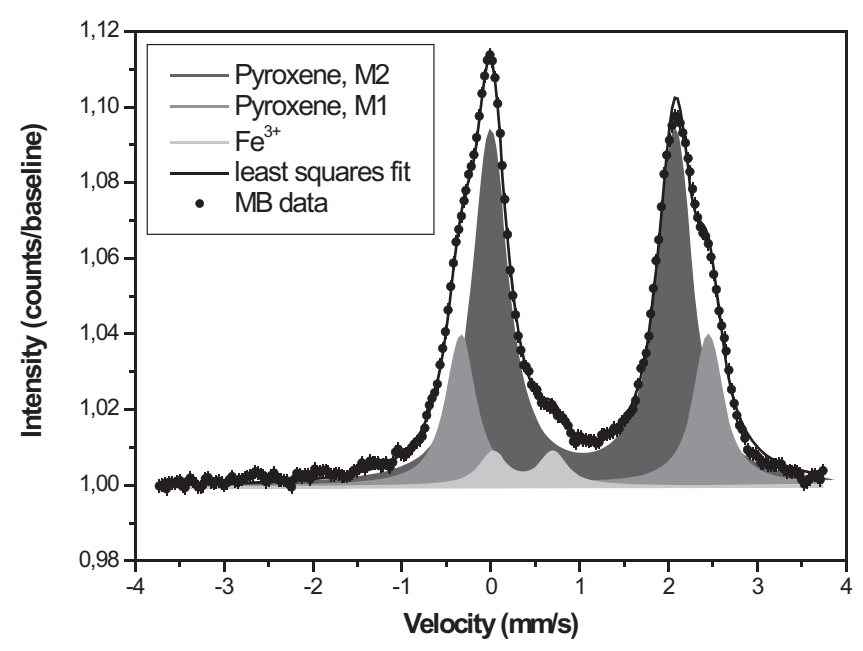

Fig. 12. Fitted Mössbauer spectrum of sol 070 Bounce Rock target Maggie (14 keV; see Table 2). The spectrum is a sum of five temperature bins over a temperature range from 200 to $250 \mathrm{~K}$.

pigeonite and augite occur as separate grains in about equal proportions and are zoned from $\mathrm{Mg}$-rich cores to Fe-rich rims.
Christensen et al. (2004) compared the Mini-TES spectrum of Bounce Rock to a laboratory spectrum of EETA79001 lithology B (Bishop and Hamilton 2001). They also showed spectra and proportions of mineral endmembers selected from a spectral library that were used in deconvolution to model the measured data. The two measured spectra exhibit opposite slopes in the wavenumber range from 1150 to $800 \mathrm{~cm}^{-1}$. Overall the spectrum of Bounce Rock has a negative slope and that of EETA79001 lithology B has a positive slope. In comparison, the spectrum derived from a synthetic pigeonite used in the deconvolution of the spectrum of EETA79001 lithology B shows a positive slope and four characteristic minima. In the Bounce Rock spectrum, these minima are present; however, because of the overall negative slope no pigeonite endmember was selected in the deconvolution of this spectrum (Christensen et al. 2004). Perhaps, the synthetic pigeonite spectral endmember in the mineral spectral library did not have the appropriate composition. This possibility was also considered when Mini-TES results were compared to results of in situ instruments on rover Spirit in Gusev crater (Ruff et al. 2006; 
Table 4. Mössbauer parameters of Bounce Rock compared to other basaltic shergottites.

\begin{tabular}{|c|c|c|c|c|c|c|c|c|c|}
\hline & $\begin{array}{l}\text { Bounce } \\
\text { Rock } \\
\text { Glanz2 }\end{array}$ & $\begin{array}{l}\text { Bounce } \\
\text { Rock } \\
\text { Case } \\
\end{array}$ & $\begin{array}{l}\text { Bounce } \\
\text { Rock } \\
\text { Fips2 } \\
\end{array}$ & $\begin{array}{l}\text { Bounce } \\
\text { Rock } \\
\text { Maggie }\end{array}$ & $\begin{array}{l}\text { EETA79001 } \\
\text { Lith. B }\end{array}$ & $\begin{array}{l}\text { QUE } \\
94201^{a}\end{array}$ & Shergotty $^{\mathrm{a}}$ & Zagami $^{\mathrm{a}}$ & $\begin{array}{l}\text { Los } \\
\text { Angeles }\end{array}$ \\
\hline \multicolumn{10}{|c|}{$\mathrm{Fe}^{2+}$ pyroxene $\mathrm{M} 1$} \\
\hline $\begin{array}{c}\delta^{\mathrm{b}} \\
\left(\mathrm{mm} \mathrm{s}^{-1}\right)\end{array}$ & $1.16^{\mathrm{c}}$ & $1.17^{\mathrm{c}}$ & $1.16^{\mathrm{c}}$ & $1.16^{\mathrm{c}}$ & 1.17 & 1.16 & 1.18 & 1.18 & 1.17 \\
\hline $\begin{array}{c}\Delta E_{\mathrm{Q}}^{\mathrm{d}} \\
\left(\mathrm{mm} \mathrm{s}^{-1}\right)\end{array}$ & 2.67 & 2.59 & 2.63 & 2.63 & 2.52 & 2.64 & 2.61 & 2.58 & 2.54 \\
\hline $\begin{array}{c}A^{\mathrm{e}} \\
(\%)\end{array}$ & $29^{\mathrm{c}}$ & $25^{\mathrm{c}}$ & $26^{c}$ & $26^{\mathrm{c}}$ & 27 & 24.1 & 16.6 & 13 & 43.3 \\
\hline \multicolumn{9}{|c|}{$\mathrm{Fe}^{2+}$ pyroxene M2 } & 1.14 \\
\hline$\left(\mathrm{mm} \mathrm{s}^{-1}\right)$ & & & & & & & & & \\
\hline $\begin{array}{c}\Delta E_{\mathrm{Q}} \\
\left(\mathrm{mm} \mathrm{s}^{-1}\right)\end{array}$ & 2.04 & 2.02 & 2.07 & 2.06 & 2.03 & 2.01 & 2.11 & 1.96 & 1.96 \\
\hline $\begin{array}{c}A \\
(\%) \\
\mathrm{Fe}^{2+}\end{array}$ & $69^{c}$ & $74^{\mathrm{c}}$ & $72^{\mathrm{c}}$ & $69^{c}$ & 73 & 52.0 & 27.8 & 23.1 & 42.7 \\
\hline $\begin{array}{c}\delta \\
\left(\mathrm{mm} \mathrm{s}^{-1}\right)\end{array}$ & - & - & - & - & - & 1.13 & - & 1.15 & 1.12 \\
\hline $\begin{array}{c}\Delta E_{\mathrm{Q}} \\
\left(\mathrm{mm} \mathrm{s}^{-1}\right)\end{array}$ & - & - & - & - & - & 1.77 & - & 2.05 & 1.40 \\
\hline $\begin{array}{r}A \\
(\%)\end{array}$ & - & - & - & - & - & 16.3 & - & 62.0 & 4.4 \\
\hline Oxide & & & & & & & & & \\
\hline $\begin{array}{c}\delta \\
\left(\mathrm{mm} \mathrm{s}^{-1}\right)\end{array}$ & - & - & - & - & - & 0.94 & 1.07 & - & 0.96 \\
\hline $\begin{array}{c}\Delta E_{\mathrm{Q}} \\
\left(\mathrm{mm} \mathrm{s}^{-1}\right)\end{array}$ & - & - & - & - & - & 1.03 & 0.76 & - & 0.79 \\
\hline $\begin{array}{r}A \\
(\%)\end{array}$ & - & - & - & - & - & 3.3 & 2.4 & - & 6.6 \\
\hline $\mathrm{Fe}^{3+}$ & & & & & & & & & \\
\hline $\begin{array}{c}\delta \\
\left(\mathrm{mm} \mathrm{s}^{-1}\right)\end{array}$ & {$[0.47]$} & {$[0.47]$} & {$[0.47]$} & {$[0.47]$} & - & 0.47 & 0.55 & 0.46 & 0.48 \\
\hline $\begin{array}{c}\Delta E_{\mathrm{Q}} \\
\left(\mathrm{mm} \mathrm{s}^{-1}\right)\end{array}$ & {$[0.67]$} & {$[0.67]$} & {$[0.67]$} & {$[0.67]$} & - & 0.65 & 0.82 & 0.66 & 0.69 \\
\hline $\begin{array}{r}A \\
(\%) \\
\end{array}$ & $2^{\mathrm{c}}$ & $1^{\mathrm{c}}$ & $2^{c}$ & $4^{\mathrm{c}}$ & - & 4.3 & 3.4 & 1.9 & 3.0 \\
\hline
\end{tabular}

Note: Values in square brackets were fixed during fitting procedure.

${ }^{\mathrm{a}}$ Values from Dyar (2003), whole rock samples.

${ }^{\mathrm{b}}$ Center shift, relative to $\alpha$-Fe. Uncertainty is $\pm 0.02 \mathrm{~mm} \mathrm{~s}^{-1}$.

${ }^{\mathrm{c}}$ Average value from individual temperature window fits.

${ }^{\mathrm{d}}$ Quadrupole splitting. Uncertainty is $\pm 0.02 \mathrm{~mm} \mathrm{~s}^{-1}$.

${ }^{\mathrm{e}}$ Relative subspectral area, $f$-factor corrected with $f\left(\mathrm{Fe}^{3+}\right) / f\left(\mathrm{Fe}^{2+}\right)=1.21$ (cf. Morris et al. 2006b). Uncertainty is $\pm 2 \%$.

McSween et al. 2008). Additionally, a negative slope in the Bounce Rock spectrum may be caused by plagioclase/pyroxene ratios and/or pigeonite/augite ratios different from those of EETA79001 lithology B (Wright 2007).

Mössbauer data permit us to constrain the pyroxene mineralogy in more detail. Spectra of Bounce Rock are dominated by two pyroxene doublets. Major cations in pyroxenes $\mathrm{Ca}, \mathrm{Mg}$, and $\mathrm{Fe}^{2+}$ occupy the centers of two nonequivalent oxygen octahedra, designated $\mathrm{M} 1$ and $\mathrm{M} 2$, with $\mathrm{Fe}^{2+}$ having a preference for M2. The distribution of $\mathrm{Fe}^{2+}$ between $\mathrm{M} 1$ and M2 can be derived by the distinct temperature dependence of a $\mathrm{MB}$ parameter, $\Delta E_{\mathrm{Q}}$, which is the quadrupole splitting defined as the distance between peak centers of a doublet. In the temperature range between 200 and $300 \mathrm{~K}, \Delta E_{\mathrm{Q}}$ for $\mathrm{M} 1$ decreases much faster with increasing temperature than $\Delta E_{\mathrm{Q}}$ for $\mathrm{M} 2$ (e.g., Regnard et al. 1987; Eeckhout et al. 2000; De Grave and Eeckhout 2003; Eeckhout and De Grave 2003). On Bounce Rock, MB spectra of four targets (Glanz2, Case, Fips2, and Maggie) were collected over diurnal 


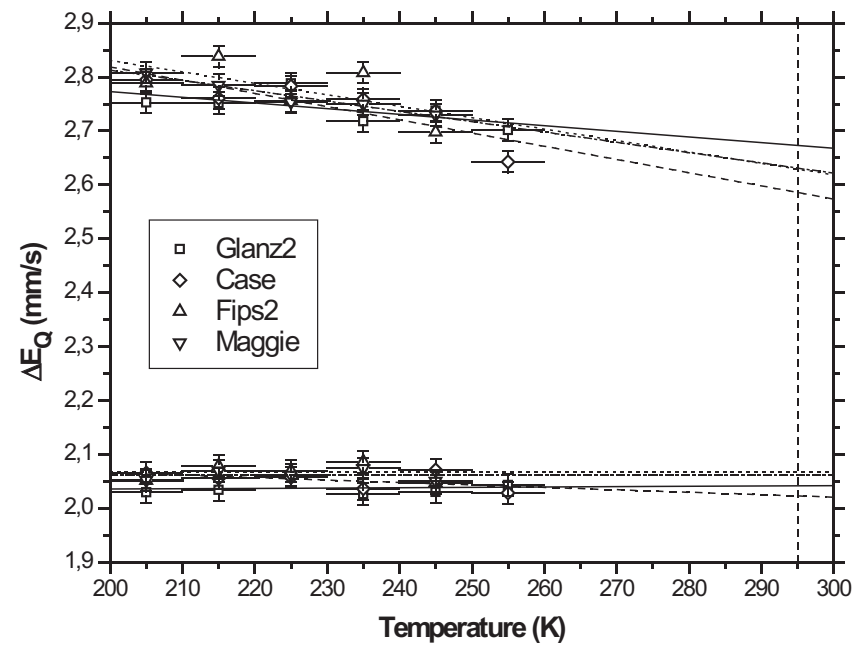

Fig. 13. Temperature dependence of the quadrupole splitting $\Delta E_{\mathrm{Q}}$ for the two $\mathrm{Fe}^{2+}$ doublets assigned to pyroxene in four different targets on Bounce Rock. Symbols are placed in the center of each temperature window and horizontal error bars represent the width of each temperature window. The doublet with larger $\Delta E_{\mathrm{Q}}$ shows a pronounced temperature dependence whereas the $\Delta E_{\mathrm{Q}}$ of the other doublet remains more or less stable. This feature is consistent with the larger $\Delta E_{\mathrm{Q}}$ doublet arising from $\mathrm{Fe}^{2+}$ in pyroxene M1 positions and the other doublet arising from $\mathrm{Fe}^{2+}$ in the pyroxene M2 site. Linear regressions for Glanz2: solid line; Case: dashed; Fips2: dotted; Maggie: dash-dot.

temperature ranges from 200 to $260 \mathrm{~K}$. All spectra were split into individual temperature bins $10 \mathrm{~K}$ wide and analyzed separately. Although theoretically the temperature behavior of $\Delta E_{\mathrm{Q}}$ is not strictly linear (cf. Eeckhout et al. 2000; Eeckhout and De Grave 2003; De Grave and Eeckhout 2003 for details), we applied linear regression and extrapolated to $295 \mathrm{~K}$ to obtain approximate values of $\Delta E_{\mathrm{Q}}$. This allows us to compare our data to $\mathrm{MB}$ parameters reported for pyroxenes in Martian meteorites, which are generally obtained at room temperature, and we find good agreement (Table 4). The dominant doublet in spectra from Bounce Rock arises from $\mathrm{Fe}^{2+}$ sited in $\mathrm{M} 2$, which is preferentially occupied by $\mathrm{Ca}$ in high-Ca pyroxenes. This result indicates therefore the predominance of pyroxene with intermediate to low $\mathrm{Ca}$. By analogy with the Martian meteorites this is most likely pigeonite. The minor doublet results from $\mathrm{Fe}$ sited in $\mathrm{M} 1$ in a high-Ca pyroxene (most likely augite) and/or pigeonite (Fig. 13; Tables 4 and 5). Proportions of relative subspectral areas derived for pyroxenes in target Case, as well as for other surface targets, are in excellent agreement with those of EETA79001 lithology B and are consistent with those of QUE 94201. Pyroxenes in the Shergotty, Zagami, and Los Angeles meteorites have clearly different MB parameters (Table 4).

\section{Relationship to Martian Meteorites and Mars}

Martian meteorites are igneous basaltic and ultramafic rocks that indicate formation by partial melting of evolved source regions with broadly similar compositions (McSween and Treiman 1998). They are linked together by an oxygen isotopic composition fractionated in a common reservoir (Clayton and Mayeda 1996) and by other geochemical characteristics. The subgroup of basaltic shergottites comprises basalts with clinopyroxenes, both pigeonite and augite, as major minerals.

Bounce Rock's texture is compatible with that of an igneous rock. It has a pyroxene mineralogy comparable to that of some basaltic shergottites. Its chemical composition is compatible with that of an igneous basalt on the basis of total alkalis versus $\mathrm{SiO}_{2}$ (Le Bas et al. 1986). As pointed out above, Bounce Rock is very similar in bulk composition to two basaltic shergottites, lithology B of EETA79001 and QUE 94201.

Certain geochemical properties deduced from the composition of basaltic rocks among meteorites, lunar, and terrestrial samples are widely used to characterize material from distinct planetary bodies (e.g., Dreibus and Wänke 1985; Drake et al. 1989). One of the distinguishing geochemical properties is that the compatible elements remain mostly unfractionated during igneous processes and therefore constrain the chemical composition of the mantle source. Phosphorous and $\mathrm{Fe}$ concentrations, and $\mathrm{Ca} / \mathrm{Al}$ and $\mathrm{Fe} / \mathrm{Mn}$ weight ratios in basaltic shergottites (Table 1) were compared to basalts from Earth, Moon, and the presumed parent body for HEDs (howardites, eucrites, and diogenites), Vesta, and were used to define Marstypical properties (see also McSween et al. 2009). Bounce Rock and olivine-rich basalts analyzed at Gusev crater and Pathfinder soil-free rock have such Marstypical properties (Figs. 14 and 15). This consistency is a direct indicator that Bounce Rock and Martian meteorites are indeed derived from Mars.

\section{Origin of Bounce Rock}

On the basis of our findings, we propose that Bounce Rock is a fragmented rock ejected from an impact on Mars that was not accelerated sufficiently to leave Mars' gravity field. It is a decimeter-sized rock that is mainly composed of silicates and has chemical properties characteristic of Mars (e.g., Fe/Mn ratio). Therefore, it appears unlikely that Bounce Rock, itself, is a meteorite. The thin atmosphere on Mars does not sufficiently slow incoming objects of such masses to prevent them from shattering upon impact (Bland and Smith 2000). In fact, the only "exotic rocks" of 


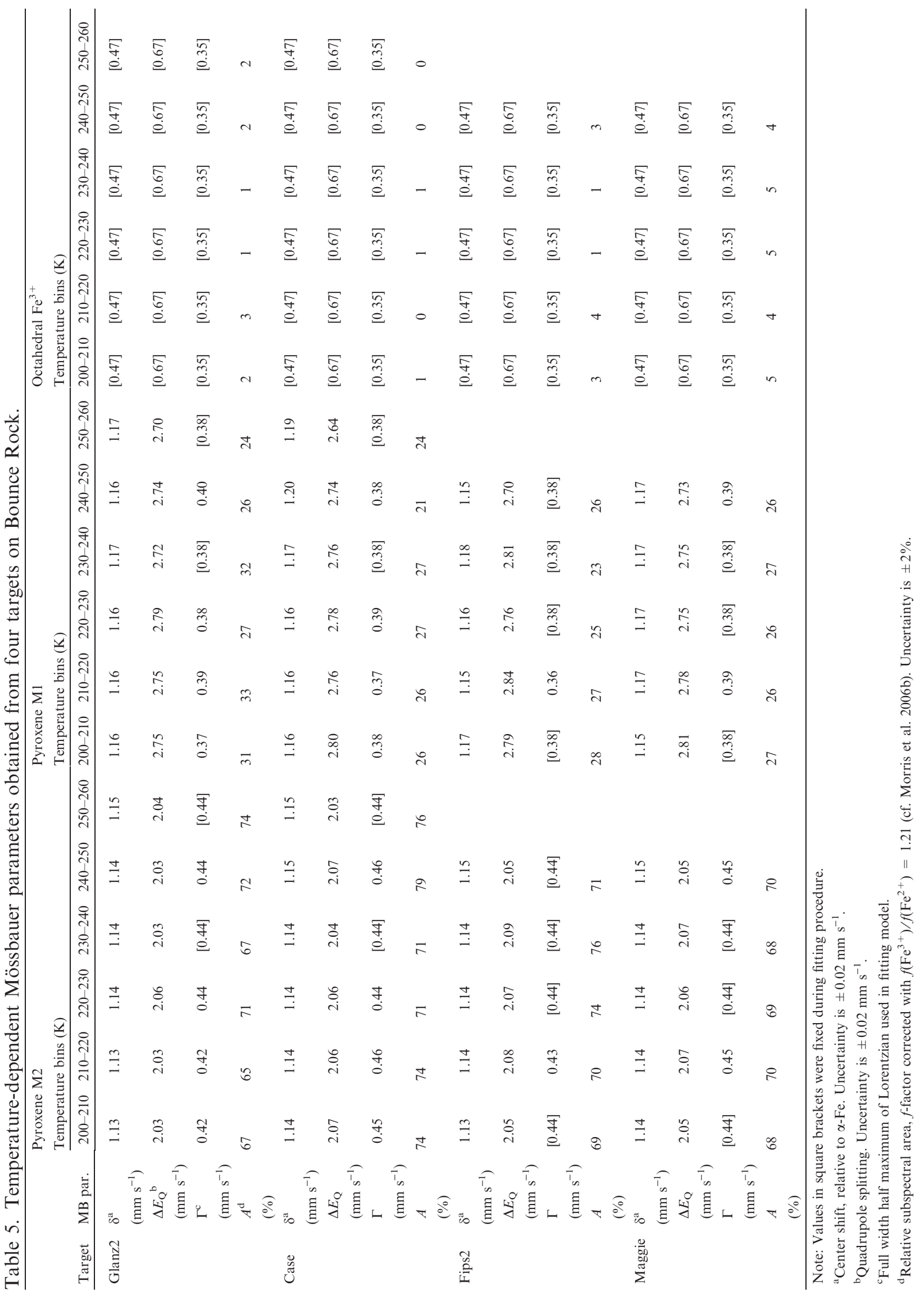




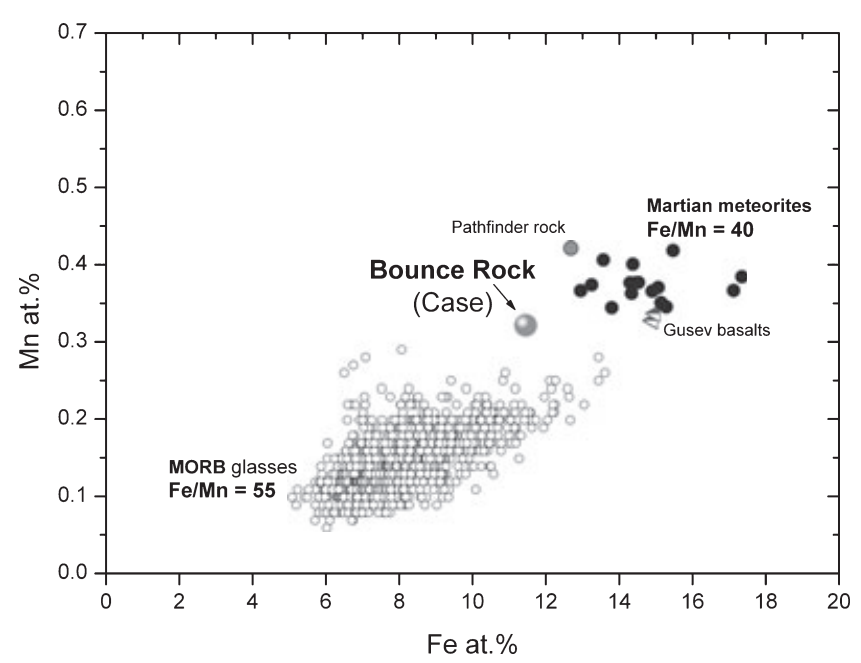

Fig. 14. Bounce Rock and other rocks on Mars have bulk $\mathrm{Fe} / \mathrm{Mn}$ atomic ratios similar to those of basaltic, olivinephyric, and lherzolitic shergottites. Data sources are given in Fig. 11. Compositions of terrestrial MORB glasses from basalts with $\mathrm{SiO}_{2}$ between 45 and $52 \mathrm{wt} \%$ are shown for comparison (data source GEOROC at http://georoc.mpchmainz.gwdg.de/georoc/).

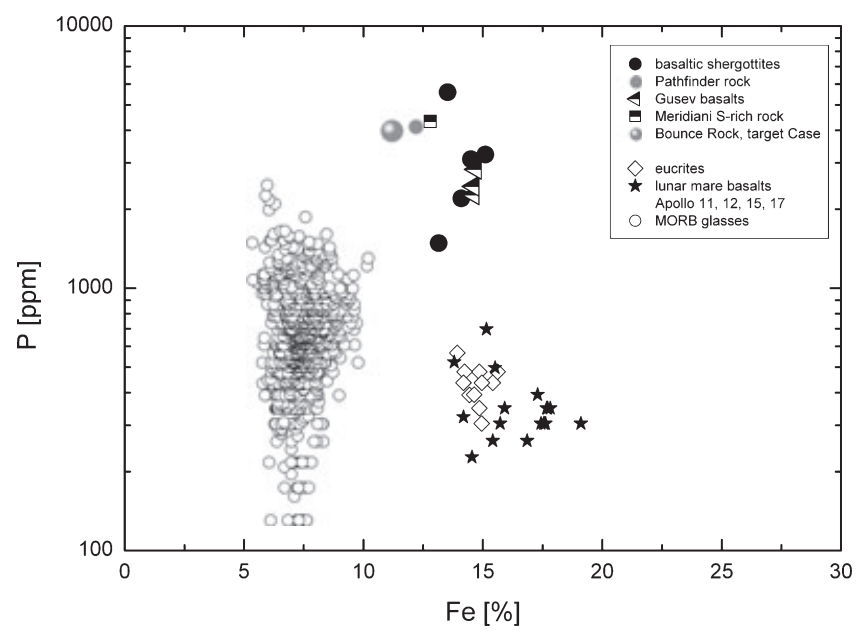

Fig. 15. Concentrations of $\mathrm{P}$ (in ppm) versus $\mathrm{Fe}$ (in $\mathrm{wt} \%$ ) in basalts from Earth, Moon, HEDs, and basaltic shergottites. Bounce Rock and other basalts analyzed on Mars have properties that are taken to be typical of Mars as defined by analysis of the Martian meteorites. Data for terrestrial basalts are taken from GEOROC; data for Moon and HEDs from BVSP (1981); other data sources are given in Fig. 11.

comparable or larger size encountered in Meridiani Planum are iron meteorites, e.g., Heatshield Rock, Block Island, Shelter Island, and Mackinac Island, which all have much higher strength (Schröder et al. 2008; Fleischer et al. 2010).

Here, we speculate about the size and location of a potential source crater. The observation of a shatter-

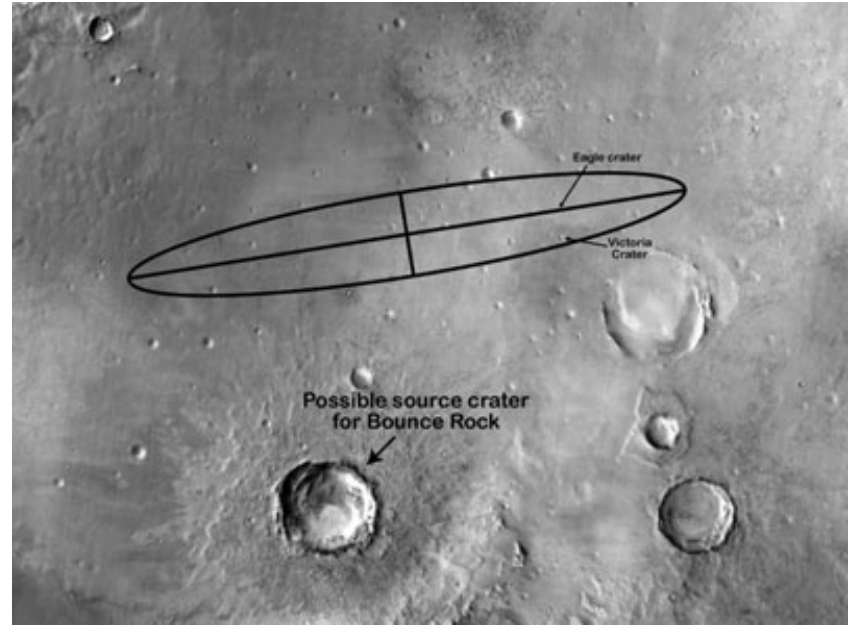

Fig. 16. Image of Meridiani Planum taken with the thermal emission imaging system on the Mars Odyssey orbiter. This image shows the estimated landing ellipse for MER-B at Meridiani Planum and big craters in the vicinity. Rays of impact ejecta emanate from Bopolu, the large crater $(19 \mathrm{~km}$ diameter) southwest of Eagle crater. Bounce Rock, found directly next to Eagle crater, falls on the extension of a ray at about $75 \mathrm{~km}$ from Bopolu crater. Bedrock studied by the rover Opportunity in Victoria, Eagle, and Endurance craters are S-rich.

cone-like surface and the relative weakness of the rock compared to other basalts on Mars (both of which may point toward the rock having been shocked) taken together with its isolated occurrence on the hematiterich plains indicate that it was ejected from an impact crater in the Meridiani region or nearby. Eagle crater and Endurance crater are about $22-130 \mathrm{~m}$ in diameter, respectively, and are located closest to Bounce Rock. However, these craters are not the source of Bounce Rock. In both of these craters, the only rocks exposed on the crater walls and floors are sulfate-rich sandstones. Although Endurance crater may have excavated to a depth of several tens of meters-greater than the current depth of the crater-orbital data suggest that the sediments at the Meridiani site are hundreds of meters in thickness (Hynek et al. 2002). Even Victoria crater, which is several $\mathrm{km}$ from Bounce Rock and approximately $800 \mathrm{~m}$ in diameter, does not appear to have excavated completely through the Meridiani sediments (Squyres et al. 2009).

Model calculations (Head et al. 2002) show that impactors about $150 \mathrm{~m}$ in diameter producing craters of approximately $3 \mathrm{~km}$ may accelerate fragments in the decimeter size range to velocities higher than the Mars escape velocity of $5 \mathrm{~km} \mathrm{~s}^{-1}$. Using fall statistics and crystallization ages, volume and estimated soil thickness at an assumed target site, Head et al. (2002) further inferred that source craters for EETA79001 and the other shergottites could have been as small as $3-4 \mathrm{~km}$ 
diameter. Such material must have been ejected in close proximity to the impactor's edge from within the crater. Material more distant from ground zero, yet still within the crater, may have been ejected at spall velocities too low to leave Mars' gravity field. Therefore, we might expect a significant fraction of ejected material from relatively small craters to scatter over the surface of Mars. As pointed out by Head et al. (2002), the range in exposure ages and the lack of $2 \pi$ exposure make it unlikely that a single crater is the source of all shergottites.

Bounce Rock's location within discontinuous rays of a crater approximately $19 \mathrm{~km}$ in diameter and located $75 \mathrm{~km}$ to the southwest at $2.95 \mathrm{~S}$ and $6.33 \mathrm{~W}$ (Fig. 16) makes this crater a possible candidate (Squyres et al. 2004b). In 2006, this crater was officially named Bopolu. Its size easily exceeds the minimum size of a crater needed to launch material from Mars (Melosh 1984; Head et al. 2002). Additional evidence that Bopolu may be the source crater for Bounce Rock comes from TES data mapping of the hematite distribution at Meridiani Planum. Unlike its surroundings, Bopolu crater samples material that is not hematite rich (Hamilton et al. 2003). These authors further screened TES data for potential source craters for Martian meteorites by taking TES spectra of Los Angeles, Zagami, ALHA77005, Nakhla, ALH 84001, and Chassigny as representative endmembers. Although Bopolu did not register as a source match for Los Angeles or Zagami material in a TES deconvolution, neither did any other crater on Mars. It is of course possible that the source rocks for these materials are distributed on a scale that is below that of TES resolution. Although the TES results leave the identity of a potential source crater in question, Bopolu as the source crater for Bounce Rock is the simplest interpretation.

\section{CONCLUSIONS}

Bounce Rock is unique on the plains of Meridiani in many respects. At Meridiani, Planum rocks are typically exposed inside craters and are very S-rich and of sedimentary origin. The texture, mineralogy, and chemistry of Bounce Rock, however, indicate an igneous origin. Bounce Rock has a pyroxene-rich mineralogy as deduced from Mini-TES and Pancam spectra, Mössbauer analyses, and APXS bulk compositional data. Although there is some disagreement between instrument results about the composition of pyroxenes in Bounce Rock the pyroxene content is clearly high, approximately $55 \mathrm{vol} \%$ according to Mini-TES results. Fits to Mini-TES spectra are consistent with the pyroxene consisting mostly of Ca-rich clinopyroxene. Mössbauer data, on the other hand, indicate a predominance of medium- to low-Ca pyroxene (pigeonite), with subordinate high-Ca pyroxene (augite), similar to the pyroxene in lithology B of EETA79001 and QUE 94201. A relationship to these two basaltic shergottites is strongly indicated by Bounce Rock's bulk chemistry determined by the APXS. Possible shock features support the interpretation that Bounce Rock is a piece of distal impact ejecta, and Bopolu crater (19 km diameter), located $75 \mathrm{~km}$ to the southwest, is the most likely source crater. In Bounce Rock, a rock with the characteristic Martian chemical fingerprint (e.g., $\mathrm{Fe} / \mathrm{Mn}$ ratio and $\mathrm{P}$ concentration) and a shergottite-like bulk composition has been analyzed for the first time on Mars. This finding provides additional direct evidence of a Martian origin for the shergottite meteorites.

Acknowledgments-The authors thank the Meteorite Working Group and the curator for Antarctic meteorites, Kevin Righter, for loan of an unpolished butt of EETA79001. Some of this research was carried out at and for the Jet Propulsion Laboratory, California Institute of Technology, sponsored by the National Aeronautics and Space Administration. This article has benefitted greatly from reviews of an earlier version of the manuscript by Phil Bland, Cyrena Goodrich, Takashi Mikouchi, Deon van Niekerk, and Larry Nittler. We also thank M. Schmidt, E. Walton, and Alan Treiman for their reviews.

\section{Editorial Handling-Dr. Alan Treiman}

\section{REFERENCES}

Arvidson R. E., Anderson R. C., Bartlett P., Bell J. F. III, Christensen P. R., Chu P., Davis K., Ehlmann B., Golombek M. P., Gorevan S., Guinness E. A., Haldemann A. F. C., Herkenhoff K. E., Landis G., Li R., Lindemann R., Ming D. W., Myrick T., Parker T., Richter L., Seelos F. P. IV, Soderblom L. A., Squyres S. W., Sullivan R. J., and Wilson J. 2004. Localization and physical property experiments conducted by Opportunity at Meridiani Planum. Science 306:1730-1733, doi:10.1126/science. 1104211.

Arvidson R. E., Squyres S. W., Anderson R. C., Bell J. F. III, Blaney D., Brückner J., Cabrol N. A., Calvin W. M., Carr M. H., Christensen P. R., Clark B. C., Crumpler L., Des Marais D. J., de Souza P. A. Jr., d'Uston C., Economou T., Farmer J., Farrand W. H., Folkner W., Golombek M., Gorevan S., Grant J. A., Greeley R., Grotzinger J., Guinness E., Hahn B. C., Haskin L., Herkenhoff K. E., Hurowitz J. A., Hviid S., Johnson J. R., Klingelhöfer G., Knoll A. H., Landis G., Leff C., Lemmon M., Li R., Madsen M. B., Malin M. C., McLennan S. M., McSween H. Y., Ming D. W., Moersch J., Morris R. V., Parker T., Rice J. W. Jr., Richter L., Rieder R., Rodionov D. S., Schröder C., Sims M., Smith M., Smith P., Soderblom L. 
A., Sullivan R., Thompson S. D., Tosca N. J., Wang A., Wänke H., Ward J., Wdowiak T., Wolff M., and Yen A. 2006. Overview of the Spirit Mars Exploration Rover mission to Gusev crater: Landing site to Backstay Rock in the Columbia Hills. Journal of Geophysical Research 111:E02S01, doi:10.1029/2005JE002499.

Arvidson R. E., Ruff S. W., Morris R. V., Ming D. W., Crumpler L. S., Yen A. S., Squyres S. W., Sullivan R. J., Bell J. F., Cabrol N. A., Clark B. C., Farrand W. H., Gellert R., Greenberger R., Grant J. A., Guinness E. A., Herkenhoff K. E., Hurowitz J. A., Johnson J. R., Klingelhöfer G., Lewis K. W., Li R., McCoy T. J., Moersch J., McSween H. Y., Murchie S. L., Schmidt M., Schröder C., Wang A., Wiseman S., Madsen M. B., Goetz W., and McLennan S. M. 2008. Spirit Mars rover mission to the Columbia Hills, Gusev crater: Mission overview and selected results from the Cumberland Ridge to Home Plate. Journal of Geophysical Research 113:E12S33, doi:10.1029/2008JE003183.

Banin A., Clark B. C., and Wänke H. 1992. Surface chemistry and mineralogy. In Mars, edited by Kieffer H. H., Jakosky B. M., Snyder C. W., and Matthews M. S. Tucson, Arizona: The University of Arizona Press. pp. 594-625.

Barrat J. A., Gillet P., Sautter V., Jambon A., Javoy M., Göpel C., Lesourd M., Keller F., and Petit E. 2002. Petrology and chemistry of the basaltic shergottite Northwest Africa 480. Meteoritics \& Planetary Science 37:487-499.

Bell J. F. III, Squyres S. W., Herkenhoff K. E., Maki J. N., Arneson H. M., Brown D., Collins S. A., Dingizian A., Elliot S. T., Hagerott E. C., Hayes A. G., Johnson M. J., Johnson J. R., Joseph J., Kinch K., Lemmon M. T., Morris R. V., Scherr L., Schwochert M., Shepard M. K., Smith G. H., Sohl-Dickstein J. N., Sullivan R. J., Sullivan W. T., and Wadsworth M. 2003. Mars Exploration Rover Athena Panoramic Camera (Pancam) investigation. Journal of Geophysical Research 108:8063, doi:10.1029/2003JE002070.

Bell J. F. III, Squyres S. W., Arvidson R. E., Arneson H. M., Bass D., Calvin W., Farrand W. H., Goetz W., Golombek M., Greeley R., Grotzinger J., Guinness E., Hayes A. G., Hubbard M. Y. H., Herkenhoff K. E., Johnson M. J., Johnson J. R., Joseph J., Kinch K. M., Lemmon M. T., Li R., Madsen M. B., Maki J. N., Malin M., McCartney E., McLennan S., McSween H. Y. Jr., Ming D. W., Morris R. V., Noe Dobrea E. Z., Parker T. J., Proton J., Rice J. W. Jr., Seelos F., Soderblom J. M., Soderblom L. A., SohlDickenstein J. N., Sullivan R. J., Weitz C. M., and Wolff M. J. 2004. Pancam multispectral imaging results from the Opportunity rover at Meridiani Planum. Science 306:17031709.

Bell J. F. III, Joseph J., Sohl-Dickstein J. N., Arneson H. M., Johnson M. J., Lemmon M. T., and Savransky D. 2006. In-flight calibration and performance of the Mars Exploration Rover Panoramic Camera (Pancam) instruments. Journal of Geophysical Research 111:E02S03, doi:10.1029/2005JE002444.

Bishop J. L. and Hamilton V. E. 2001. Reflectance and emittance spectra of Martian meteorites (abstract). Meteoritics \& Planetary Science 36:A21.

Bland P. A. and Smith T. B. 2000. Meteorite accumulation on Mars. Icarus 144:21-26, doi:10.1006/icar.1999.6253.

Bogard D. D. and Johnson P. 1983. Martian gases in an Antarctic meteorite? Science 221:651-654, doi:10.1126/ science. 221.4611 .651 .
Borg L. E., Nyquist L. E., Taylor L. A., Wiesmann H., and Shih C.-Y. 1997. Constraints on Martian differentiation processes from $\mathrm{Rb}-\mathrm{Sr}$ and $\mathrm{Sm}-\mathrm{Nd}$ isotopic analyses of the basaltic shergottite QUE 94201. Geochimica et Cosmochimica Acta 61:4915-4931, doi:10.1016/S00167037(97)00276-7.

Brückner J., Dreibus G., Rieder R., and Wänke H. 2003. Refined data of APXS analyses of soils and rocks at the Mars Pathfinder site: Implications for surface chemistry. Journal of Geophysical Research 108:8094, doi:10.1029/ 2003JE002060.

BVSP. 1981. Basaltic Volcanism Study Project. Basaltic volcanism on the terrestrial planets. New York: Pergamon Press, Inc. 1286 p.

Christensen P. R., Mehall G. L., Silverman S. H., Anwar S., Cannon G., Gorelick N., Kheen R., Tourville T., Bates D., Ferry S., Fortuna T., Jeffryes J., O’Donnell W., Peralta R., Wolverton T., Blaney D., Denise R., Rademacher J., Morris R. V., and Squyres S. 2003. Miniature Thermal Emission Spectrometer for the Mars Exploration Rovers. Journal of Geophysical Research 108:8064, doi: 10.1029/2003JE002117.

Christensen P. R., Wyatt M. B., Glotch T. D., Rogers A. D., Anwar S., Arvidson R. E., Bandfield J. L., Blaney D. L., Budney C., Calvin W. M., Fallacaro A., Fergason R. L., Gorelick N., Graff T. G., Hamilton V. E., Hayes A. G., Johnson J. R., Knudson A. T., McSween H. Y. Jr., Mehall G. L., Mehall L. K., Moersch J. E., Morris R. V., Smith M. D., Squyres S. W., Ruff S. W., and Wolff M. J. 2004. Mineralogy at Meridiani Planum from the Mini-TES experiment on the Opportunity rover. Science 306:17331739, doi:10.1126/science.1104909.

Clayton R. N. and Mayeda T. K. 1996. Oxygen isotope studies of achondrites. Geochimica et Cosmochimica Acta 60:1999-2017.

De Grave E. and Eeckhout S. G. 2003. ${ }^{57}$ Fe Mössbauer-effect studies of Ca-rich, Fe-bearing clinopyroxenes: Part III. Diopsode. American Mineralogist 88:1145-1152.

Drake M. J., Newson J. H., and Capobianco C. J. 1989. V, $\mathrm{Cr}$, and $\mathrm{Mn}$ in the Earth, Moon, EPB and SPB and the origin of the Moon: Experimental studies. Geochimica et Cosmochimica Acta 53:2101-2111.

Dreibus G. and Wänke H. 1985. Mars, a volatile-rich planet. Meteoritics 20:367-381.

Dyar M. D. 2003. Ferric iron in SNC meteorites as determined by Mössbauer spectroscopy: Implications for Martian landers and Martian oxygen fugacity. Meteoritics \& Planetary Science 38:1733-1752.

Eeckhout S. G. and De Grave E. 2003. ${ }^{57} \mathrm{Fe}$ Mössbauer-effect studies of Ca-rich, Fe-bearing clinopyroxenes: Part I. Paramagnetic spectra of magnesian hedenbergite. American Mineralogist 88:1129-1137.

Eeckhout S. G., De Grave E., McCammon C. A., and Vochten R. 2000. Temperature dependence of the hyperfine parameters of synthetic $P 2_{1} / c \quad \mathrm{Mg}-\mathrm{Fe}$ clinopyroxenes along the $\mathrm{MgSiO}_{3}-\mathrm{FeSiO}_{3}$ join. American Mineralogist 85:943-952.

Fleischer I., Klingelhöfer G., Schröder C., Mittlefehldt D. W., Morris R. V., Golombek M., and Ashley J. W. 2010. In situ investigation of iron meteorites at Meridiani Planum, Mars (abstract \#1791). 41st Lunar and Planetary Science Conference. CD-ROM.

Fleischer I., Klingelhöfer G., Schröder C., Morris R. V., Hahn M., Rodionov D., Gellert R., and de Souza P. A. Jr. 2008. 
Depth selective Mössbauer spectroscopy: Analysis and simulation of $6.4 \mathrm{keV}$ and $14.4 \mathrm{keV}$ spectra obtained from rocks at Gusev crater, Mars, and layered laboratory samples. Journal of Geophysical Research 113:E06S21, doi:10.1029/2007JE003022.

Foley C. N., Economou T., and Clayton R. N. 2003. Final chemical results from the Mars Pathfinder Alpha Proton X-ray Spectrometer. Journal of Geophysical Research 108:8096, doi:10.1029/2002JE002019.

Gellert R., Rieder R., Anderson R. C., Brückner J., Clark B. C., Dreibus G., Economou T., Klingelhöfer G., Lugmair G. W., Ming D. W., Squyres S. W., d'Uston C., Wänke H., Yen A., and Zipfel J. 2004. Chemistry of rocks and soils in Gusev crater from the Alpha Particle X-ray Spectrometer. Science 203:829-832, doi:10.1126/science. 1099913.

Gellert R., Rieder R., Brückner J., Clark B. C., Dreibus G., Klingelhöfer G., Lugmair G., Ming D. W., Wänke H., Yen A., Zipfel J., and Squyres S. W. 2006. Alpha Particle X-Ray Spectrometer (APXS): Results from Gusev crater and calibration report. Journal of Geophysical Research 111:E02S05, doi:10.1029/2005JE002555.

GEOROC. http://georoc.mpch-mainz.gwdg.de/georoc/Entry. html.

Gibson H. M. and Spray J. G. 1998. Shock-induced melting and vaporization of shatter cone surfaces: Evidence from the Sudbury impact structure. Meteoritics \& Planetary Science 33:329-336.

Gorevan S. P., Myrick T., Davis K., Chau J. J., Bartlett P., Mukherjee S., Anderson R., Squyres S. W., Arvidson R. E., Madsen M. B., Bertelsen P., Goetz W., Binau C. S., and Richter L. 2003. The Rock Abrasion Tool: Mars Exploration Rover mission. Journal of Geophysical Research 108:8068.

Hamilton V. E., Christensen P. R., McSween H. Y. Jr., and Bandfield J. L. 2003. Searching for the source regions of Martian meteorites using MGS TES: Integrating Martian meteorites into the global distribution of igneous materials on Mars. Meteoritics \& Planetary Science 38:871-885.

Head J. N., Melosh H. J., and Ivanov B. A. 2002. Martian meteorite launch: High-speed ejecta from small craters. Science 298:1752-1756.

Herkenhoff K. E., Squyres S. W., Bell J. F. III, Maki J. N., Arneson H. M., Bertelsen P., Brown D. I., Collins S. A., Dingizian A., Elliot S. T., Goetz W., Hagerott E. C., Hayes A. G., Johnson J. R., Kirk R. L., McLennan S., Morris R. V., Scherr L. M., Schwochert M. A., Shiraishi L. R., Smith G. H., Soderblom J. M., Sohl-Dickstein J. N., and Wadsworth M. V. 2003. The Athena Microscopic Imager investigation. Journal of Geophysical Research 108:8065, doi:10.1029/2003JE00207.6.

Herkenhoff K. E., Squyres S. W., Arvidson R., Bass D. S., Bell J. F. III, Bertelsen P., Ehlmann B. L., Farrand W., Gaddis L., Greeley R., Grotzinger J., Hayes A. G., Hviid S. F., Johnson J. R., Jolliff B., Kinch K. M., Knoll A. H., Madsen M. B., Maki J. N., McLennan S. M., McSween H. Y. Jr., Ming D. W., Rice J. W. Jr., Richter L., Sims M., Smith P. H., Soderblom L. A., Spanovich N., Sullivan R., Thompson S., Wdowiak T., Weitz C., and Whelley P. 2004. Evidence from Opportunity's Microscopic Imager for water on Meridiani Planum. Science 306:1727-1730, doi:10.1126/science. 1105286 .

Herkenhoff K. E., Grotzinger J., Knoll A. H., McLennan S. M., Weitz C., Yingst A., Anderson R., Archinal B. A.,
Arvidson R. E., Barrett J. M., Becker K. J., Bell J. F., Budney C., Chapman M. G., Cook D., Ehlmann B., Franklin B., Gaddis L. R., Galuszka D. M., Garcia P. A., Geissler P., Hare T. M., Howington-Kraus E., Johnson J. R., Keszthelyi L., Kirk R. L., Lanagan P., Lee E. M., Leff C., Maki J. N., Mullins K. F., Parker T. J., Redding B. L., Rosiek M. R., Sims M. H., Soderblom L. A., Spanovich N., Springer R., Squyres S. W., Stolper D., Sucharski R. M., Sucharski T., Sullivan R., and Torson J. M. 2008. Surface processes recorded by rocks and soils on Meridiani Planum, Mars: Microscopic Imager observations during Opportunity's first three extended missions. Journal of Geophysical Research 113:E12S32, doi:10.1029/ 2008JE003100.

Hynek B. M., Arvidson R. E., and Phillips R. 2002. Geologic setting and origin of Terra Meridiani hematite deposit on Mars. Journal of Geophysical Research 107:18-1, doi:10.1029/2002E001891.

Jambon A., Barrat J. A., Sautter V., Gillet P., Göpel C., Javoy M., Joron J. L., and Lesourd M. 2002. The basaltic shergottite Northwest Africa 856: Petrology and chemistry. Meteoritics \& Planetary Science 37:1147-1164.

Jolliff B. L., Farrand W. H., Johnson J. R., Schröder C., Weitz C. M., and the Athena Science Team. 2006. Origin of rocks and cobbles on the Meridiani Plains as seen by Opportunity (abstract \#2401). 37th Lunar and Planetary Science Conference. CD-ROM.

Klingelhöfer G., Morris R. V., Bernhardt B., Rodionov D., de Souza P. A. Jr., Squyres S. W., Foh J., Kankeleit E., Bonnes U., Gellert R., Schröder C., Linkin S., Evlanov E. N., Zubkov B., and Prilutski O. 2003. Athena MIMOS II Mössbauer Spectrometer investigation. Journal of Geophysical Research 108:8067.

Klingelhöfer G., Morris R. V., Bernhardt B., Schröder C., Rodionov D. S., de Souza P. A. Jr., Yen A., Gellert R., Evlanov E. N., Zubkov B., Foh J., Bonnes U., Kankeleit E., Gütlich P., Ming D. W., Renz F., Wdowiak T., Squyres S. W., and Arvidson R. E. 2004. Jarosite and hematite at Meridiani Planum from Opportunity's Mössbauer Spectrometer. Science 306:1740-1745, doi:10.1126/science.1104653.

Le Bas M. J., Le Maitre R. W., Streckeisen A., and Zanettin B. 1986. A chemical classification of volcanic rocks based on the total alkali-silica diagram. Journal of Petrology 27:745-750.

Lee D.-C. and Halliday A. N. 1997. Core formation on Mars and differentiated asteroids. Nature 388:854-857.

Lodders K. 1998. A survey of shergottite, nakhlite and chassigny meteorites whole-rock compositions (abstract). Meteoritics \& Planetary Science 33:A183-A190.

Lugmair G. W. and Shukolyukov A. 1998. Early solar system time scales according to ${ }^{53} \mathrm{Mn}-{ }^{53} \mathrm{Cr}$ systematics. Geochimica et Cosmochimica Acta 62:2863-2886.

Maki J. N., Bell J. F., Herkenhoff K. E., Squyres S. W., Kiely A., Klimesh M., Schwochert M., Litwin T., Willson R., Johnson A., Maimone M., Baumgartner E., Collins A., Wadsworth M., Elliot S. T., Dingizian A., Brown D., Hagerott E. C., Scherr L., Deen R., Alexander D., and Lorre J. 2003. Mars Exploration Rover engineering cameras. Journal of Geophysical Research 108:8071, doi:10.1029/2003JE002077.

McSween H. Y. and Treiman A. H. 1998. Martian meteorites. In Planetary materials, edited by Papike J. Reviews in Mineralogy, vol. 36. pp. 6-1-6-53. 
McSween H. Y., Arvidson R. E., Bell J. F. III, Blaney D. L., Cabrol N. A., Christensen P. R., Clark B. C., Crisp J. A., Crumpler L. S., Des Marais D. J., Farmer J. D., Gellert R., Ghosh A., Gorevan S. P., Graff G., Grant J., Haskin L. A., Herkenhoff K. E., Johnson J. R., Jolliff B., Klingelhöfer G., Knudson A. T., McLennan S., Milam K. A., Moersch J. E., Morris R. V., Rieder R., Ruff S. W., de Souza P. A. Jr., Squyres S. W., Wänke H., Wang A., Wyatt M. B., Yen A., and Zipfel J. 2004. Basaltic rocks analyzed by the Spirit rover in Gusev crater. Science 305:842-845.

McSween H. Y., Wyatt M. B., Gellert R., Bell J. F. III, Morris R. V., Herkenhoff K. E., Crumpler L. S., Milam K. A., Stockstill K. R., Tornabene L. L., Arvidson R. E., Bartlett P., Blaney D., Cabrol N. A., Christensen P. R., Clark B. C., Crisp J. A., Des Marais D. J., Economou T., Farmer J. D., Farrand W., Ghosh A., Golombek M., Gorevan S., Greeley R., Hamilton V. E., Johnson J. R., Jolliff B. L., Klingelhöfer G., Knudson A. T., McLennan S., Ming D., Moersch J. E., Rieder R., Ruff S. W., Schröder C., de Souza P. A. Jr., Squyres S. W., Wänke H., Wang A., Yen A., and Zipfel J. 2006. Characterization and petrologic interpretation of olivine-rich basalts at Gusev crater, Mars. Journal of Geophysical Research 111:E02S10, doi:10.1029/2005JE002477.

McSween H. Y. J., Taylor G. J., and Wyatt M. B. 2009. Elemental composition of the Martian crust. Science 324:736-739.

McSween H. Y., Ruff S. W., Morris R. V., Gellert R., Klingelhöfer G., Christensen P. R., McCoy T. J., Ghosh A., Moersch J. M., Cohen B. A., Rogers A. D., Schröder C., Squyres S. W., Crisp J., and Yen A. 2008. Mineralogy of volcanic rocks in Gusev crater, Mars: Reconciling Mössbauer, APXS, and Mini-TES spectra. Journal of Geophysical Research 113:E06S04, doi:10.1029/2007 JE002970.

Melosh H. J. 1984. Impact ejection, spallation, and the origin of meteorites. Icarus 59:234-260.

Mikouchi T., Miyamoto M., and McKay G. A. 1999. The role of undercooling in producing igneous zoning trends in pyroxenes and maskelynites among basaltic Martian meteorites. Earth and Planetary Science Letters 173:235256.

Milton D. J. and De Carli P. S. 1963. Maskelynite: Formation by explosive shock. Science 140:670-671.

Morris R. V., Klingelhöfer G., Schröder C., Rodionov D. S., Yen A., Ming D. W., de Souza P. A. Jr., Fleischer I., Wdowiak T., Gellert R., Bernhardt B., Evlanov E. N., Zubkov B., Foh J., Bonnes U., Kankeleit E., Gütlich P., Renz F., Squyres S. W., and Arvidson R. E. $2006 \mathrm{a}$. Mössbauer mineralogy of rock, soil, and dust at Gusev crater, Mars: Spirit's journey through weakly altered olivine basalt on the plains and pervasively altered basalt in the Columbia Hills. Journal of Geophysical Research 111:E02S13, doi:10.1029/2005JE002584.

Morris R. V., Klingelhöfer G., Schröder C., Rodionov D. S., Yen A., Ming D. W., de Souza P. A. Jr., Wdowiak T., Fleischer I., Gellert R., Bernhardt B., Bonnes U., Cohen B. A., Evlanov E. N., Foh J., Gütlich P., Kankeleit E., McCoy T., Mittlefehldt D. W., Renz F., Schmidt M. E., Zubkov B., Squyres S. W., and Arvidson R. E. 2006b. Mössbauer mineralogy of rock, soil, and dust at Meridiani Planum, Mars: Opportunity's journey across sulfate-rich outcrop, basaltic sand and dust, and hematite lag deposits.
Journal of Geophysical Research 111:E12S15, doi:10.1029/ 2006JE002791.

Nicolaysen L. O. and Reimold W. U. 1999. Vredefort shatter cones revisited. Journal of Geophysical Research 104:49114930.

Nyquist L. E., Bogard D. D., Shih C.-Y., Greshake A., Stöffler D., and Eugster O. 2001. Ages and geologic histories of Martian meteorites. Space Science Reviews 96:105-164.

Regnard J. R., Greneche J. M., and Guillen R. 1987. Temperature dependence of the hyperfine parameters of a natural orthopyroxene $\mathrm{Fe}_{0.87} \mathrm{Mg}_{0.13} \mathrm{SiO}_{3}$. Solid State Communications 63:277-283.

Rieder R., Gellert R., Brückner J., Klingelhöfer G., Dreibus G., Yen A., and Squyres S. W. 2003. The new Athena Alpha Particle X-ray Spectrometer for the Mars Exploration Rovers. Journal of Geophysical Research 108:8066, doi:10.1029/2003JE002150.

Rieder R., Gellert R., Anderson R. C., Brückner J., Clark B. C., Dreibus G., Economou T., Klingelhöfer G., Lugmair G. W., Ming D. W., Squyres S. W., d'Uston C., Wänke H., Yen A., and Zipfel J. 2004. Chemistry of rocks and soils at Meridiani Planum from the Alpha Particle X-ray Spectrometer. Science 306:1746-1749.

Ruff S. W., Christensen P. R., Blaney D. L., Farrand W. H., Johnson J. R., Michalski J. R., Moersch J. E., Wright S. P., and Squyres S. W. 2006. The rocks of Gusev crater as viewed by the Mini-TES instrument. Journal of Geophysical Research 111:E12S18, doi:10.1029/2006JE002747.

Savransky D. and Bell J. F. III. 2004. True color and chromaticity of the Martian surface and sky from Mars Exploration Rover Pancam observations. EOS Transactions $A G U$, abstract P21A-0197.

Schröder C., Rodionov D. S., McCoy T. J., Jolliff B. L., Gellert R., Nittler L. R., Farrand W. H., Johnson J. R., Ruff S. W., Ashley J. W., Mittlefehldt D. W., Herkenhoff K. E., Fleischer I., Haldemann A. F. S., Klingelhöfer G., Ming D. W., Morris R. V., de Souza P. A. Jr., Squyres S. W., Weitz C., Yen A. S., Zipfel J., and Economou T. 2008. Meteorites on Mars observed with the Mars Exploration Rovers. Journal of Geophysical Research 113:E06S22, doi:10.1029/2007JE002990.

Squyres S. W., Arvidson R. E., Bell J. F. III, Brückner J., Cabrol N. A., Calvin W., Carr M. H., Christensen P. R., Clark B. C., Crumpler L., Des Marais D. J., d'Uston C., Economou T., Farmer J., Farrand W., Folkner W., Golombek M., Gorevan S., Grant J. A., Greeley R., Grotzinger J., Haskin L., Herkenhoff K. E., Hviid S., Johnson J., Klingelhöfer G., Knoll A., Landis G., Lemmon M., Li R., Madsen M. B., Malin M. C., McLennan S. M., McSween H. Y., Ming D. W., Moersch J., Morris R. V., Parker T., Rice J. W. Jr., Richter L., Rieder R., Sims M., Smith M., Soderblom L. A., Sullivan R., Wänke H., Wdowiak T., Wolff M., and Yen A. 2004a. The Spirit rover's Athena science investigation at Gusev crater, Mars. Science 305:794-799, doi: 10.1126/ science. 3050794.

Squyres S. W., Arvidson R. E., Bell J. F. III, Brückner J., Cabrol N. A., Calvin W., Carr M. H., Christensen P. R., Clark B. C., Crumpler L., Des Marais D. J., d'Uston C., Economou T., Farmer J., Farrand W., Folkner W., Golombek M., Gorevan S., Grant J. A., Greeley R., Grotzinger J., Haskin L., Herkenhoff K. E., Hviid S., Johnson J., Klingelhöfer G., Knoll A., Landis G., 
Lemmon M., Li R., Madsen M. B., Malin M. C., McLennan S. M., McSween H. Y., Ming D. W., Moersch J., Morris R. V., Parker T., Rice . J. W. Jr., Richter L., Rieder R., Sims M., Smith M., Soderblom L. A., Sullivan R., Wänke H., Wdowiak T., Wolff M., and Yen A. 2004b. The Opportunity rover's Athena science investigation at Meridiani Planum, Mars. Science 306:1689-1703.

Squyres S. W., Knoll A. H., Arvidson R. E., Clark B. C., Grotzinger J. P., Jolliff B. L., McLennan S. M., Tosca N., Bell J. F. III, Calvin W. M., Farrand W. H., Glotch T. D., Golombek M. P., Herkenhoff K. E., Johnson J. R., Klingelhöfer G., McSween H. Y., and Yen A. S. 2006a. Two years at Meridiani Planum: Results from the Opportunity rover. Science 313:1403-1407, doi:10.1126/ science. 1130890.

Squyres S. W., Arvidson R. E., Bollen D., Bell J. F. III, Brückner J., Cabrol N. A., Calvin W. M., Carr M. H., Christensen P. R., Clark B. C., Crumpler L., Des Marais D. J., d'Uston C., Economou T., Farmer J., Farrand W. H., Folkner W., Gellert R., Glotch T. D., Golombek M., Gorevan S., Grant J. A., Greeley R., Grotzinger J., Herkenhoff K. E., Hviid S., Johnson J. R., Klingelhöfer G., Knoll A. H., Landis G., Lemmon M., Li R., Madsen M. B., Malin M. C., McLennan S. M., McSween H. Y., Ming D. W., Moersch J., Morris R. V., Parker T., Rice J. W. Jr., Richter L., Rieder R., Schröder C., Sims M., Smith M., Smith P., Soderblom L. A., Sullivan R., Tosca N. J., Wänke H., Wdowiak T., Wolff M., and Yen A. 2006b. Overview of the Opportunity Mars Exploration Rover mission to Meridiani Planum: Eagle crater to Purgatory Ripple. Journal of Geophysical Research 111:E12S12, doi:10.1029/2006JE002771.
Squyres S. W., Knoll A. H., Arvidson R. E., Ashley J. W., Bell J. F., Calvin W. M., Christensen P. R., Clark B. C., Cohen B. A., de Souza P. A., Edgar L., Farrand W. H., Fleischer I., Gellert R., Golombek M. P., Grant J., Grotzinger J., Hayes A., Herkenhoff K. E., Johnson J. R., Jolliff B., Klingelhöfer G., Knudson A., Li R., McCoy T. J., McLennan S. M., Ming D. W., Mittlefehldt D. W., Morris R. V., Rice J. W., Schröder C., Sullivan R. J., Yen A., and Yingst R. A. 2009. Exploration of Victoria crater by the Mars Rover Opportunity. Science 324:1058-1061.

Steele I. M. and Smith J. V. 1982. Petrography and mineralogy of two basalts and olivinepyroxene-spinel fragments in achondrite EETA79001. Proceedings, 13th Lunar and Planetary Science Conference. Journal of Geophysical Research 87:A375-A384.

Wieland F., Reimold W. U., and Gibson R. L. 2006. New observations on shatter cones in the Vredefort impact structure, South Africa, and evaluation of current hypotheses for shatter cone formation. Meteoritics \& Planetary Science 41:1737-1759.

Wright S. P. 2007. The basaltic shergottites: Constraints on their existence on Mars, ejection, and characteristics (but not location) of their source region/crater from their geochemistries and terrestrial analog fieldwork (abstract \#3399). Seventh International Conference on Mars. Pasadena, California: Jet Propulsion Laboratory.

Zipfel J., Anderson R., Brückner J., Clark B. C., Dreibus G., Economou T., Gellert R., Klingelhöfer G., Lugmair G. W., Ming D. W., Rieder R., Squyres S. W., d'Uston C., Wänke H., Yen A., and Team A. S. 2004. APXS analyses of Bounce Rock-The first shergottite on Mars (abstract). Meteoritics \& Planetary Science 39:A118. 